\title{
Karşılaşılan Duygusal ve Davranışsal Problemlerin Ebeveyn Tutumu ile İlişkisinin İncelenmesi: İçerik Analizi
}

\author{
DOI: $10.26466 /$ opus.907851
}

\author{
Aysel Çoban *-Zehra Bilgen **- Özge İdrisoğlu ***- İlyas Sönmez **** \\ Hatice Berna Türe Köse *****- Hatice Ünlü Bozkurt****** \\ * Doç. Dr., Hacettepe Üniversitesi, Eğitim Fakültesi, Ankara/Türkiye \\ E-Posta: aysel.coban@hacettepe.edu.tr \\ ORCID: $\quad \underline{0000-0002-0631-0064}$ \\ ** Arş.Gör., Çanakkale Onsekiz Mart Üniversitesi, Eğitim Fakültesi, Çanakkale/Türkiye \\ E-Posta: zehragunduz@comu.edu.tr \\ ORCID: $\quad \underline{0000-0002-4146-3090}$ \\ *** Arş.Gör., Fatih Sultan Mehmet Vakıf Üniversitesi, Eğitim Fakültesi, İstanbul/Türkiye \\ E-Posta: oidrisoglu@fsm.edu.tr \\ ORCID: $\quad \underline{0000-0002-9254-0059}$ \\ **** Arş.Gör., Hacettepe Üniversitesi, Eğitim Fakültesi, Ankara/Türkiye \\ E-Posta: ilyassonmez@hacettepe.edu.tr ORCID: $\quad \underline{\text { 0000-0003-1161-9397 }}$ \\ ***** Arş.Gör., Kütahya Dumlupınar Üniversitesi, Eğitim Fakültesi, Kütahya/Türkiye \\ E-Posta: haticeberna.ture@dpu.edu.tr ORCID: $\underline{\text { 0000-0001-5382-3885 }}$ \\ ******Öğr. Gör., İstanbul Gelişim Üniversitesi, İstanbul/Türkiye \\ E-Posta: hbozkur@@gelisim.edu.tr $\quad$ ORCID: $\quad \underline{\text { 0000-0002-9129-3536 }}$ \\ Öz
}

Bu araştırmada, 2005-2020 yilları arasinda "Dergipark", "Ulakbim" ve "Acarindex" veri tabanlarinda duygusal ve davranışsal problemler (DDP) ile ebeveyn tutumunun birlikte ele alındığı çalışmaların bir analizi yapılmıştır. Bu kapsamda yapılan çalışmalarda ele alınan duygusal ve davranışsal problemlerin ebeveyn tutumlarıla nasıl ilişkilendirildiğ i, DDP ile ebeveyn tutumlarna yönelik sonuçların neler olduğu ve çalışmalarda ele alınan demografik değişkenler, ölçme araçları, araştırma yöntem ve tekniklerine göre içerik analizi yapılması hedeflenmiştir. 0-18 yaş aralı̆̆ndaki duygusal davranışsal problemlerin ebeveyn tutumu ile ilişkilendirildiğ çalışmaları incelemek amacıyla (tematik) içerik analizi yöntemi kullanılmıştır. Bu kapsamda ele alnan 41 makale indekslerine, yayınlanma yılına, DDP türüne, disiplin alanına, çalş̧ma alanına, araştırma yöntemine, incelenen yaş grubuna ve kullanılan ölçeklere göre incelenmiş ve bulgular tablo ve grafiklerle sunulmuştur. Buna göre incelenen makalelerin 2018 ve 2019 yıllarında yoğunlaştığı, çoğunlukla davranım bozukluğunun ele alındığı, bu probleme takiben dikkat eksikliği ve hiperaktivite bozukluğu ve kaygı bozukluğunun ele alınmış olduğu bulgulanmıştır. Yöntem bakımından bir makale dışında tüm makalelerin nicel yöntemi kullandığı ve çalışma grubu olarak sirasiyla ergenlik dönemi, okul öncesi dönem ve ilkokul dönemindeki çocuklarda görülen DDP'nin ebeveyn tutumu ile ilişkilendirildiği tespit edilmiştir.

Anahtar Kelimeler: duygusal problemler, davranışsal problemler, ebeveyn tutumu, içerik analizi. 


\title{
Examining the Relationship between Emotional and Behavioral Problems and Parental Attitude: Content Analysis
}

\begin{abstract}
In this research, the studies between 2005-2020 years on emotional and behavioral problems and parental attitudes published in national databases "Dergipark", "Ulakbim" and "Acarindex" were analyzed. It was aimed to investigate these studies in terms of the relationship between emotional and behavioral problems and parental attitudes, demographic variables, scales, research methods and techniques. Thematic content analysis (meta-synthesis) method was used to examine the studies in which emotional and behavioral problems of children aged 0-18 were associated with parental attitude. 41 articles which have been published between 2005 and 2020 and found in databases of "Dergipark", "Ulakbim/TR Dizin" and "Acarindex" were included in the study. In this context, the articles were analyzed according to the database, publication year, the type of emotional and behavioral problems, discipline area, study area, research method, age group of the sample and the scales; so, the findings are presented in tables and graphics. It was concluded that articles have increased in 2018 and 2019, concentrated mostly on conduct disorder, attention deficit and hyperactivity disorder, and anxiety disorder. It was found that quantitative research methods were generally used in the studies and the sample group was respectively the children in adolescence, preschool, and primary school period.
\end{abstract}

Key Words: Emotional problems and behavioral problems, parental attitude, content analysis. 


\section{Giriş}

Çocuklar donmamış beton gibidir, üzerlerine ne düşse iz bırakır.

Haim Ginott

Çocuğun bir davranışı yapmaması gerektiğini bildiği halde tekrarlayıcı bir şekilde yaşına, toplumun sosyal ve kültürel yapısına uymayan duygusal ve davranışsal tepkiler göstermesi problemli davranış olarak değerlendirilmektedir (Birkan, 2002; Özel Eğitim Hizmetleri Yönetmeliği, 2006). Gözlenen davranışların hepsi problem davranış olarak adlandırılmamaktadır. Bir davranışın problem davranış olarak ele alınması için bu davranışın sıklığı, süresi ve şiddeti kadar çocuğun yaşantısını da olumsuz yönde etkilemesi gerekmekte ve bu nedenle müdahaleye gerek duyulmaktadır (Campbell, 1995). Duygusal ve davranışsal problemler, okulun ilk yıllarında memnuniyetsizlik, otoriteye karşı gelme olarak görülürken, ergenlik yıllarında şiddetlenerek hırsızlık yapma ve yalan söyleme gibi davranışlara dönüşebilmekte ve ilerleyen yıllarda cinayet, darp ve vandalizm gibi büyük davranış sorunlarına yol açabilmektedir. (Beard ve Sugai, 2004). Duygusal ve davranışsal probleme sahip olan çocuk ve ergenler, çoğunlukla sosyal çevresine karşı yıkıcı, dürtüsel, saldırgan, rahatsız edici tutum ve davranışlar sergileyebilmektedirler (Cancio ve Johnson, 2013; Golly, Sprague, Walker, Beard ve Gorham, 2000).

Duygusal ve davranışsal problemler içselleştirici ve dışsallaştırıcı olmak üzere ikiye ayrılmaktadır. Gözlenmesi ve değerlendirilmesi daha zor olan içselleştirici problemler depresyon, içe dönüklük, obsesif-kompulsif problemler, anksiyete ve travma sonrası stres bozukluğu gibi problemlerdir. Net olarak gözlemlenebilen dışsallaştırıcı problemler ise saldırganlık, hiperaktivite, sosyal sorunlar, kurallara karşı koyma ve dikkat eksikliği gibi davranışta gözlenebilen problemlerdir (Austin ve Sciarra, 2019).

Çocuk ve ergenlerde görülen duygusal ve davranışsal problemlerin ortaya çıkmasında birçok etken rol oynamaktadır. Çocuğun içinde bulunduğu ailede yoksulluk, şiddet, ihmal ve istismar olması çocukların davranış problemleri göstermesinde risk faktörü oluşturmaktadır (Conroy ve Brown, 2004). Akranlarla yaşanılan iletişim sorunları, okul yaşantısı, travmalar, genetik faktörler ve olumsuz ebeveyn davranışları da 
çocuk ve ergenlerde davranış problemlerinin ortaya çıkmasında tetikleyici olabilmektedir (Arkan ve Üstün, 2009). Anne babaların olumsuz davranışlarına ek olarak, çocuk yetiştirirken sergilemiş olduğu otoriter, demokratik, aşırı koruyucu ya da izin verici tutumlarının da çocuğun yaşantısı ve gelişimi üzerinde olumlu ya da olumsuz etkileri bulunmaktadir (Arl, 2005).

Demokratik ebeveyn tutumuna sahip anne babalar çocuklarına karşı destekleyici, her durumda çocuklarının kendi fikirlerini açıklamalarına fırsat tanıyan ve çocuğun kişisel çıkarları ile kendi yetişkin hakları arasında dengeyi sağlayan yetişkinlerdir. Aile içerisinde takip edilen kurallar konusunda tutarlı ve otorite sahibidirler (Baumrind, 1966, 1971; Trawick-Smith, 2017). Bu tutuma sahip ebeveynlerin çocuklarının özgüvenleri ve öz-düzenlemeleri yüksek, keşfeden, yaşıtları ile iyi iletişim kuran bağımsız bireyler olabildikleri görülmektedir (Baumrind, 1971).

Otoriter ebeveyn tutumu, anne babanın çocuğu ile daha mesafeli ilişkiler kurduğu, kendi isteklerinin karşı gelinmesine fırsat tanımayan ve çocuk üzerinde aşırı kontrol kurmaya çalıştığı ve aksi takdirde zorlayıcı cezalar uyguladığı tutumdur. Ebeveynlerin otoriter olduğu bir aile ortamında çocukların içe kapanık, şikayetkâr, güvensiz ve yaşıtlarıyla zayıf ilişkiler kurduğu görülmüştür (Baumrind, 1966; Trawick-Smith, 2017). Aynı zamanda, bu çocukların yüksek düzeyde kaygı bozukluğu ve asosyal davranışlar gösterdiği de yapılan çalışmalarla ortaya konmuştur (Hale, 2008).

İzin verici ebeveyn tutumu anne babaların çocuğun istek ve davranışlarına karşı hoşgörülü ve kabullenici olduğu tutumdur. Demokratik ebeveyn tutumunun aksine, çocuğun aşırı özgürlüğü ve kontrolsüzlüğü söz konusudur (Baumrind, 1966). Yapılan çalışmalarda bu tutumun çocuklar üzerinde özgüven, öz-kontrol, bağımlılık ve sosyal açıdan olumsuz etkileri olduğu bulunmuştur (Trawick-Smith, 2017).

Aşırı koruyucu ebeveyn tutumu ebeveyn ve çocuk arasında aşırı temas, çocuğu bebekleştirme, onun sosyal gelişiminin önlenmesi ve aşırı özen gibi temel davranışları içermektedir (Levy, 1966, akt., KarabulutDemir, 2007). Ebeveynin bu tutumu karşısında çocuklar, çevresinde bulunan bireylere aşırı bağımlı, özgüvensiz ve duygusal olarak hassas kişiler haline gelebilmektedir (Yavuzer, 2008). 
Yavuzer (2008) çocuk ve ergenlerin olumlu davranışlar geliştirmesini sağlamanın yolunu hoşgörülü, destekleyici ve sevgi dolu yaklaşımlarla mümkün olduğunu, aksi bir ortama maruz kalan çocukların karmaşık düşünce, duygu ve ikilemler yaşadığını ve bu nedenle birtakım uyum sorunlarının ortaya çıktığını ifade etmektedir. Senemoğlu (2009) da ebeveynlerin çocuk yetiştirirken sergiledikleri tutumların çocukların duygusal ve davranışsal özelliklerini ve tüm gelişim alanlarını önemli düzeyde etkilediğine vurgu yapmaktadır.

Tüm bu bilgiler ışığında çocuk ve ergenlerde görülen duygusal ve davranışsal problemler ile ebeveyn tutumlarına ilişkin çalışmalar alan yazında incelenmiş ve ebeveyn tutumlarının çocukların davranışlarını şekillendirmede önemli bir role sahip olduğu ve bu çalışmaların çoğunlukla 2005-2020 yılları arasında yayınlandığı tespit edilmiştir. Ayanoğlu ve diğerleri (2019) çocukluk döneminde görülen duygusal ve davranışsal problemleri temel alan tezleri incelemiş ve tezleri yıllara, problemlere ve disiplin alanına göre gruplandırmışlardır. Çalışmada problemlerin herhangi bir değişken ile ilişkilendirilmediği ve sadece tezlerin incelendiği görülmüştür. Sümer, Gündoğdu-Aktürk ve Helvacı (2010) ise anne baba tutum ve davranışlarının çocuklar üzerindeki psikolojik etkilerini görmek amacıyla, örneklemi Türkiye'den seçilen ve ulusal ya da uluslararası dergilerde yayınlanmış çalışmaları inceleyerek derleme makalesi oluşturmuştur. Bu çalışma da ise duygusal ve davranışsal problemler ile ebeveyn tutumları arasındaki ilişkiyi ortaya koyarak, bu konu üzerine çalışmalar yapan uzman ve araştırmacılara ek olarak alandaki uygulayıcı ve ebeveynlere toplu bir bakış sağlaması hedeflenmektedir.

Bu amaçla, 2005-2020 tarihleri arasında yapılan çalışmalarda ebeveyn tutumları ile duygusal ve davranışsal problemlerin nasıl ilişkilendirildiği, duygusal ve davranışsal problemler ile ebeveyn tutumlarına yönelik sonuçların neler olduğu ve çalışmalarda ele alınan demografik değişkenler, ölçme araçları, araştırma yöntem ve tekniklerine göre içerik analizi yapılması hedeflenmiştir. Yapılan bu içerik analizi çalışması ile birçok çalışmanın sonuçları incelenmiş ve derlemesi yapılmıştır. Yapılan bu çalışmanın sonucunda, duygusal ve davranışsal problemler ile ebeveyn tutumlarının incelenmesinin çocuk gelişimi uzmanları, okul öncesi öğretmenleri, erken çocukluk hizmet alanlarında çalışan uzmanlar ve ebeveynlere de önemli bilgiler sağlayacağı düşünülmektedir. 
Bu doğrultuda Türkçe veri tabanlarında yayınlanan makaleler taranarak yapılan çalışmanın amacı doğrultusunda ebeveyn tutumları ile çocuk ve ergenlerde görülen duygusal ve davranışsal problemleri konu edinen makaleler incelenmiş ve aşağıdaki sorulara cevap aranmıştır.

Araştırmaya dahil edilen veri tabanlarında yer alan 2005-2020 yılları arasında yayınlanmış makalelerde;

- hangi veri tabanında yayınlanmıştır?

- konu edinilen duygusal ve davranışsal problemlere göre hangi yıllarda yığılma görülmektedir?

- hangi duygusal ve davranışsal problemler konu edilmiştir?

- hangi disiplin ve çalışma alanları tarafından ortaya konulmuştur?

- hangi araştırma yöntemleri kullanılmıştır?

- hangi yaş grupları çalışmaya dahil edilmiştir?

- ebeveyn tutumunu ortaya koymak üzere hangi ölçme araçları kullanılmıştır?

- duygusal ve davranışsal problemlerin tespitinde hangi ölçme araçları kullanılmıştır?

- duygusal ve davranışsal problemler, ebeveyn tutumları ile nasıl ilişkilendirilmiştir?

\section{Yöntem}

Bu çalışmada 0-18 yaş aralığındaki kişilerin duygusal ve davranışsal problemler ile ebeveyn tutumlarını birlikte ele alan 2005-2020 yılları arasındaki Türkiye'de yapılan çalışmaları incelemek amacıyla tematik içerik analizi yöntemi kullanılmıştır.

İçerik analizi sözel veya yazılı materyallerin içeriğine odaklanan ve içeriğin nesnel ve sistematik bir şekilde anlatımına olanak sağlayan bilimsel bir yaklaşımdır (Kızıltepe, 2021). İçerik analizi ile kitap, kitap bölümü, mektup, tarihsel dokümanlar, gazete yazıları gibi metinler belirli kurallara dayalı kodlamalar yapılarak bazı sözcüklerin daha küçük içerik kategorileri ile özetlenir (Büyüköztürk ve diğerleri, 2012). Bu sayede, farklı kaynaklardaki kelimelerin, kavramların, deyimlerin ve temaların varl1ğını belirlemeye ve sayıya dökmeye yönelik sistematik bir analiz yapılır (Kızıltepe, 2021). Ayrıca, içerik analizinde araştırılan bilginin yaygınlaştı- 
rılmasında ve gelecek araştırma ve uygulamaların yönlendirilmesinde etkili olan sentezler de yapılır (Suri ve Clarke, 2009). Özellikle eğitim ve sosyal bilimler gibi farklı çeşitlilikte ve konularda araştırmaların olduğu alanlarda, araştırmacılara doğrudan ve bütünsel bir bakış açısı sağlayarak araştırılan konunun genel yapısının derinlemesine anlaşılmasına yardimci olur.

İçerik analizi; meta analiz, meta-sentez (tematik içerik analizi) ve betimsel içerik analizi olarak üç başlık altında toplanmaktadır. Çalışmada duygusal ve davranışsal problemler ile ebeveyn tutumuna ilişkin çalışmaları incelemek amacıyla tematik içerik analizi (meta-sentez) yöntemi kullanılmıştır. Tematik içerik analizi (meta-sentez) çalışmaları aynı konu üzerine yapılan araştırmaların tema veya ana şablonlar aracılığıyla sentezlenerek yorumlanmasını içermektedir (Çalık ve Sözbilir, 2014). Böylece, bir konunun farklı boyutlarını ele alan çalışmaların benzerlik ve farklılıklarının karşılaştırmalı olarak ortaya konulmasıyla araştırmacılara ve öğretmenlere bir kaynak oluşturulur. Meta-sentez (tematik içerik analizi) çalışmalarında genellikle incelemeye alınan araştırma sayısı yani örneklem büyüklügü betimsel içerik analizine ve meta-analize kıyasla daha az olmaktadır (Çalık ve Sözbilir, 2014).

Yapılan bu çalışmada, ulusal veri tabanlarında duygusal ve davranışsal problemler ile ebeveyn tutumuna ilişkin 2005-2020 yılları arasında yayınlanan makalelere odaklanılmış ve makaleler çeşitli değişkenler açısından analiz edilerek açıklanmaya çalışılmıştır. Çalışmada belirlenen kriterlerle ulaşılan duygusal ve davranışsal problemler ile ebeveyn tutumuna ilişkin çalışmaların ortak, benzer veya farklı boyutlarıly birlikte derinlemesine incelenmiştir. Tematik içerik analizi kapsamına alınacak makaleler araştırmacılar tarafından belirlenen ölçütlere göre veri tabanlarında taranmış ve seçilmiştir.

\section{Tarama ve Seçim Ölçütleri}

Bu çalışma, Türkiye'deki duygusal ve davranışsal problemlerin ebeveyn tutumları ile olan ilişkisini ortaya koymak amacıyla yapılmasından dolayı Türkiye'de yapılan makalelere ulaşılmak istenmiştir. Bu yüzden, Türkiye'de yaygın bir şekilde kullanılan, ulusal kapsamda çok sayıda akademik dergiye ulaşılmasını sağlayan ve temiz veri sunma amacı olan 3 
ulusal veri tabanı seçilmiş; "Dergipark", “Ulakbim/Tr Dizin" ve "Acarindex" veri tabanları taranmıştır. Veri tabanları belirli anahtar sözcükler temele alınarak incelenmiştir. Duygusal ve davranışsal problemlerin geniş kapsamlı bir biçimde ele alınabilmesi için her bir problem türü anahtar sözcük halinde araştırılmıştır. Araştırmacılar tarafından belirlenen anahtar sözcükler Tablo 1'de listelenmiştir.

Tablo 1. Veri tabanında taranan anahtar sözcükler

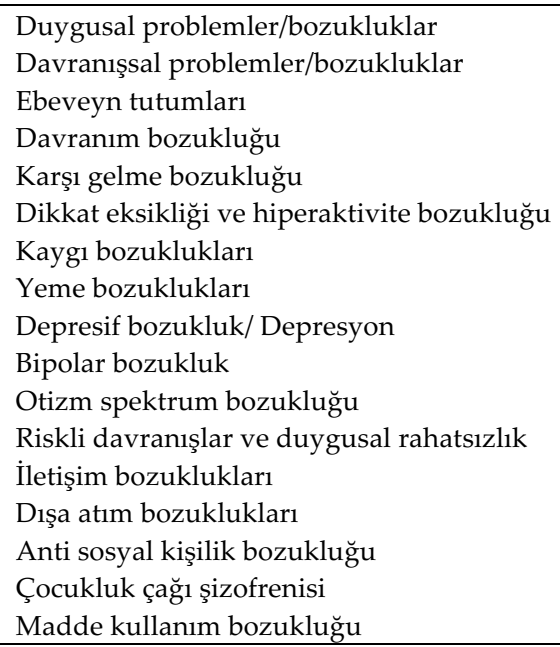

Belirlenen ölçütler doğrultusunda makaleler seçilirken, Türkiye'de yapılmış olması, 2005-2020 yılları arasında yayınlanmış olması, 0-18 yaş grubu için çalışılmış olması dikkate alınmıştır. Yetişkin yaş grubuna yönelik çalışılmış makaleler, ebeveyn tutumu çalışılmamış makaleler ve derleme makaleleri çalışma kapsamı dışında tutulmuştur. Tarama sonucunda belirlenen ölçütlere uygun olan 41 makale belirlenmiştir.

\section{Verilerin Analizi}

İçerik analizi; amaçları belirleme, kavramları tanımlama, analiz birimlerini belirleme, konu ile ilgili verilerin yerini belirleme, mantıksal bir yapıyı geliştirme, kodlama kategorilerini belirleme, sayma, yorumlama ve sonuçları yazma aşamalarıyla gerçekleştirilmektedir (Büyüköztürk ve 
diğerleri, 2012; Creswell, 2017). Bu aşamalara göre, yapılan çalışmada makalelerin içerik bilgilerine yönelik bir yayın sınıflama formu oluşturularak elde edilen veriler kaydedilmiş, kategoriler belirlenmiş, kodlamalar yapılmış ve temalara ulaşılmıştır. Bu aşamadan sonra veriler; "veri tabanı, yıl, disiplin alanı, çalışma alanı, araştırma yöntemi, yaş grubu, veri toplama araçları ve problemlerin ebeveyn tutumu ile ilişkisi" kategorilerine dayalı bir şekilde Microsoft Excel programı kullanılarak tekrarlanma sıklığı ve yüzde ile çözümlenmiş ve bu bilgilere dayalı bir şekilde yorumlanmaya çalışılmıştır. Sonuçlar grafik, frekans ve yüzde tablolarına dönüştürülerek betimsel biçimde sunulmuş ve aynı zamanda nitel boyutlarıyla ele alınmıştır.

Güvenirliğin sağlanabilmesi için bütün makaleler araştırmacılar tarafından incelenmiş ve kodlamalar yapılmıştır. İncelenen bu makaleler bütün araştırmacılar tarafından tekrar değerlendirilmiş ve görüş birliğine dayalı olarak analiz edilmesine dikkat edilmiştir. Miles ve Huberman (1994) benzeşen kodları "Görüş Birliği" ayrışan kodları ise "Görüş Ayrılığı" olarak adlandırmakta ve kodlayıcı güvenirliği için Uzlaşma Yüzdesi = Görüş Birliği / (Görüş Birliği + Görüş Ayrılığ 1$)$ * 100 formülünü önermektedir. Kodlayıcı güvenirliği için gerekli hesaplamalar formüle göre yapılmış ve kodlayıcı güvenirliği \% 88 bulunmuştur.

\section{Bulgular}

Araştırma sonucunda elde edilen bulgular tablo ve grafiklerle açıklanmıştır.

Tablo 2. Duygusal ve Davranışsal Problemlere İlişkin Ebeveyn Tutumunu İnceleyen Makalelerin Yayınlanmış Oldukları Veritabanına Göre Dă̆ılımı

\begin{tabular}{lll}
\hline Veri Tabanı & Frekans (f) & Yüzdelik (\%) \\
\hline Dergipark & 20 & 48,78 \\
Ulakbim & 20 & 48,78 \\
Acarindex & 1 & 2,44 \\
Toplam & 41 & 100,0 \\
\hline
\end{tabular}




\section{Makale Sayısı}

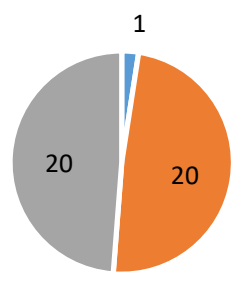

- Acarindex - Dergipark - Ulakbim

Şekil 1. Duygusal ve Davranışsal Problemlere İlişkin Ebeveyn Tutumunu İnceleyen Makalelerin Yayınlanmış Oldukları İndekslere Göre Dă̆ılımı

Tablo 2 ve Şekil 1'e göre; 2005-2020 yılları arasında duygusal ve davranışsal problemlere ilişkin ebeveyn tutumunu inceleyen makalelere bakıldığında üç farklı veri tabanında 41 makale yayınlandığı görülmektedir. Makalelerin yayınlandıkları veri tabanına göre dağılımı incelendiğinde, en fazla makalenin Dergipark ve Ulakbim veri tabanlarında yayınlandığı görülmektedir. Dergipark ve Ulakbim veri tabanlarında yayınlanan makaleler; incelenen makalelerin \%97.56'sını (40) oluşturmaktadır. Acarindex veri tabanında yayınlanan makaleler; incelenen makalelerin \%2,44 (1)'ünü oluşturmaktadır.

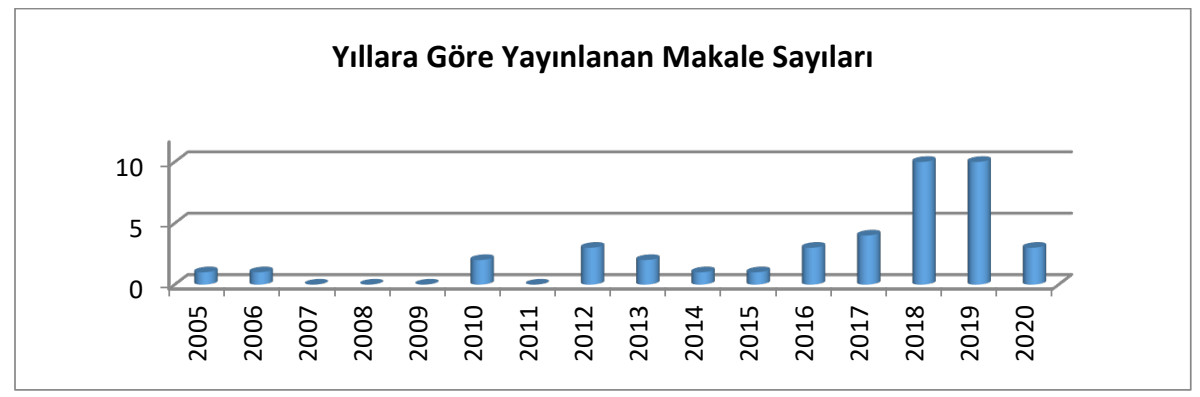

Şekil 2. Duygusal ve Davranışsal Problemlere İlişkin Ebeveyn Tutumunu İnceleyen Makalelerin Yayınlanmış Oldukları Yıllara Göre Dağılımı

Tablo 3 ve Şekil 2'de; 2005-2020 yılları arasında duygusal ve davranışsal problemlere ilişkin ebeveyn tutumunu inceleyen makalelerin 
yıllara göre dağılımı görülmektedir. Makalelerin yayınlandıkları yıllar incelendiğinde, en fazla makalenin yayınlandığı yılların 2018 ve 2019 yıllarında olduğu görülmektedir. Bu 2018 ve 2019 yıllarında yayınlanan makaleler, incelenen makalelerin \%49,78 (20)'ini oluşturmaktadır. Diğer yıllarda yayınlanan makalelerin yıllara göre dağılım oranlarının sırasıyla 2017 yllında \%9,76 (4); 2012, 2016, 2020 yıllarında \%7,32 (3); 2010, 2013 yıllarında \%4,87 (2) ve 2005, 2006, 2014, 2015 yıllarında \%2,44 (1) olduğu görülmektedir. 2007, 2008, 2009 ve 2011 yıllarında veri tabanlarında duygusal ve davranışsal problemlerle ebeveyn tutumunu inceleyen makalelere rastlanılmamıştır.

Tablo 3. Duygusal ve Davranışsal Problemlere İlişkin Ebeveyn Tutumunu İnceleyen Makalelerin Yayınlanmış Oldukları Yıllara Göre Dağılımı

\begin{tabular}{lll}
\hline Y.1 & Frekans (f) & Yüzdelik (\%) \\
\hline 2020 & 3 & 7,32 \\
2019 & 10 & 24,39 \\
2018 & 10 & 24,39 \\
2017 & 4 & 9,76 \\
2016 & 3 & 7,32 \\
2015 & 1 & 2,44 \\
2014 & 1 & 2,44 \\
2013 & 2 & 4,87 \\
2012 & 3 & 7,32 \\
2011 & - & 0 \\
2010 & 2 & 4,87 \\
2009 & - & 0 \\
2008 & - & 0 \\
2007 & - & 0 \\
2006 & 1 & 2,44 \\
2005 & 1 & 2,44 \\
Toplam & 41 & 100,0 \\
\hline
\end{tabular}


Aysel Çoban- Zehra Bilgen- Özge İdrisoğlu- İlyas Sönmez- Hatice Berna Türe Köse Hatice Ünlü Bozkurt

Tablo 4. Duygusal ve Davranışsal Problemlere İlişkin Ebeveyn Tutumunu İnceleyen Makalelerde İncelenen Duygusal ve Davranıssal Problemlerin Türlerine Göre Dă̆ılımı

\begin{tabular}{lll}
\hline DDP Türü & Frekans (f) & Yüzdelik (\%) \\
\hline Davranım Bozukluğu & 24 & 26,97 \\
Dikkat Eksikliği ve Hiperaktivite Bozukluğu & 11 & 12,36 \\
Kaygı Bozukluğu & 10 & 11,24 \\
Depresif Bozukluklar & 9 & 10,11 \\
Sosyal Uyum Bozukluğu & 7 & 7,87 \\
Somatizasyon & 5 & 5,61 \\
Madde Kullanım Bozukluğu & 4 & 4,5 \\
Riskli Davranışlar ve Duygusal Rahatsızlıklar & 4 & 4,5 \\
Dışa Atım Bozuklukları & 3 & 3,37 \\
Karşı Gelme Bozukluğu & 3 & 3,37 \\
Anti Sosyal Kişilik Bozukluğu & 1 & 1,12 \\
İletişim Bozuklukları & 1 & 1,12 \\
Yeme Bozuklukları & 2 & 2,25 \\
Uyku Bozuklukları & 2 & 2,25 \\
İternet Bağımlı̆ı̆̆ & 1 & 1,12 \\
Otizm Spektrum Bozukluğu & 1 & 1,12 \\
Toplam & 88 & 100,0 \\
\hline
\end{tabular}

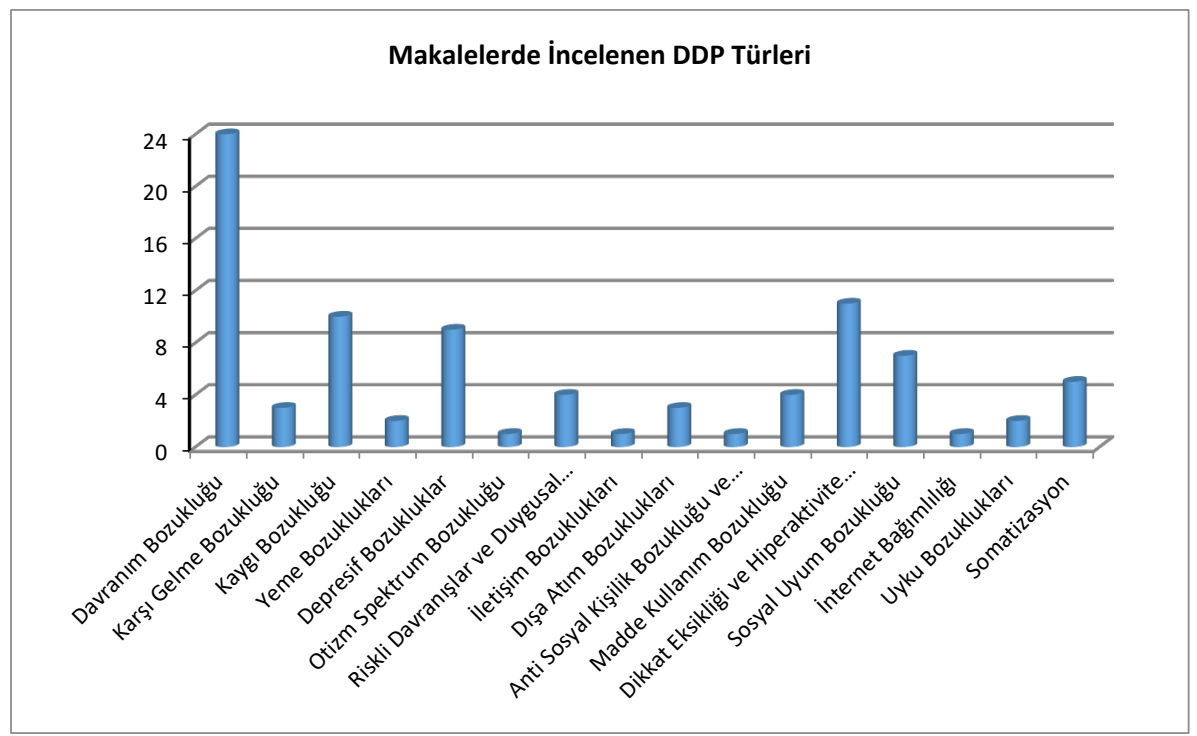

Şekil 3. Duygusal ve Davranışsal Problemlere İlişkin Ebeveyn Tutumunu İnceleyen

Makalelerde İncelenen Duygusal ve Davranışsal Problemlerin Türlerine Göre Dağılımı 
Tablo 4 ve Şekil 3'te; 2005-2020 yılları arasında duygusal ve davranışsal problemlere ilişkin ebeveyn tutumunu inceleyen makalelerde incelenen duygusal ve davranışsal problem (DDP) türlerinin dağılımı görülmektedir. Makalelerdeki duygusal ve davranışsal problem türleri incelendiğinde, en fazla duygusal ve davranışsal problemin davranım bozukluğu türünde olduğu görülmektedir. Duygusal ve davranışsal problem türü olarak davranım bozukluğunu araştıran makaleler incelenen makalelerin \%26,97'sini (24) oluşturmaktadır. Diğer duygusal ve davranışsal problemlerin incelenen makalelerdeki dağılım oranlarına bakıldığında, sırasıyla dikkat eksikliği ve hiperaktivite bozukluğu \%12,36 (11); kaygı bozukluğu \%11,24 (10); depresif bozukluklar, \%10,11 (9); sosyal uyum bozukluğu, \%7,87 (7); somatizasyon \%5,61 (5); madde kullanım bozukluğu, riskli davranışlar ve duygusal rahatsızlıklar, \%4,5 (4); karşı gelme bozukluğu, dışa atım bozuklukları \%3,37 (3); yeme bozuklukları, uyku bozuklukları \%2,25 (2) ve otizm spektrum bozukluğu, iletişim bozuklukları, anti sosyal kişilik bozukluğu, internet bağımlılı̆̆ $\% 1,12$ (1) olduğu görülmektedir.

Tablo 5. Duygusal ve Davranıssal Problemlere İlişkin Ebeveyn Tutumunu İnceleyen Makalelerin Disiplin Alanlarına Göre Dağılımı

\begin{tabular}{lll}
\hline Disiplin Alanı & Frekans (f) & Yüzdelik (\%) \\
\hline Eğitim Bilimleri & 20 & 48,78 \\
Tıp Bilimleri & 8 & 19,52 \\
Sosyal Bilimler & 7 & 17,07 \\
Sağlık Bilimleri & 6 & 14,63 \\
Toplam & 41 & 100,0 \\
\hline
\end{tabular}

\section{Disiplin Alanlarına Göre Makaleler}

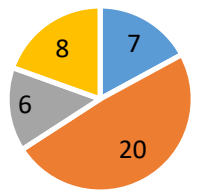

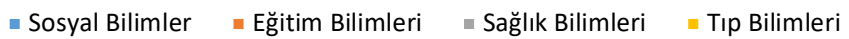

Şekil 4. Duygusal ve Davranışsal Problemlere İlişkin Ebeveyn Tutumunu İnceleyen Makalelerin Disiplin Alanlarına Göre Dağılımı 
Tablo 5 ve Şekil 4'te; 2005-2020 yılları arasında duygusal ve davranışsal problemlere ilişkin ebeveyn tutumunu inceleyen makalelerin disiplin alanlarına göre dağılımı görülmektedir. Makalelerin yayınlandıkları disiplin alanları incelendiğinde, en fazla makalenin yayınlandığı disiplin alanının "Eğitim Bilimleri" alanında olduğu görülmektedir. Eğitim Bilimleri disiplin alanında yayınlanan makaleler incelenen makalelerin \%48,78'ini (20) oluşturmaktadır. Diğer disiplin alanlarında yayınlanan makalelerin oranlarının sırasıyla "Tıp Bilimleri" disiplin alanı \%19,52 (8); "Sosyal Bilimler" disiplin alanı \%17,07 (7) ve "Sağlık Bilimleri" disiplin alanı \%14,63 (6) olduğu görülmektedir. Tablo 6'da disiplin alanlarının çalışma alanlarına göre daha detaylı incelemesine yer verilmiştir.

Tablo 6. Duygusal ve Davranıssal Problemlere İlişkin Ebeveyn Tutumunu İnceleyen Makalelerin Çalışma Alanlarına Göre Dağılımı

\begin{tabular}{llll}
\hline Çalışma Alanı & & Frekans (f) & Yüzdelik (\%) \\
\hline Sosyal Bilimler & Okul Öncesi & 11 & 26,83 \\
\hline \multirow{3}{*}{ Eğitim Bilimleri } & Psikoloji & 7 & 17,07 \\
& PDR & 5 & 12,2 \\
& Eğitim Bilimleri & 3 & 7,31 \\
& Özel Eğitim & 1 & 2,44 \\
\hline \multirow{2}{*}{ Sağlık Bilimleri } & Hemşirelik & 5 & 12,2 \\
& Beslenme ve Diyetetik & 1 & 2,44 \\
\hline \multirow{2}{*}{ Tıp Bilimleri } & Psikiyatri & 6 & 14,63 \\
& Ruh Sağlığı ve Hastalıkları & 1 & 2,44 \\
\hline Toplam & Pediatri & 1 & 2,44 \\
\hline
\end{tabular}

Tablo 6'da; 2005-2020 yılları arasında duygusal ve davranışsal problemlere ilişkin ebeveyn tutumunu inceleyen makalelerin çalışma alanlarına göre dağılımı görülmektedir. Makalelerin yayınlandıkları çalışma alanları incelendiğinde, Sosyal Bilimler disiplin alanında sadece "Psikoloji" çalışma alanında makale yayınlandığını ve oranının \%17,07 (7) olduğu görülmektedir. Eğitim Bilimleri disiplin alanında “Okul Öncesi Eğitimi", "Psikolojik Danışma ve Rehberlik" (PDR), "Eğitim Bilimleri Bölümü" ve "Özel Eğitim" çalışma alanlarında makalelerin yayınlandığ 1 görülmektedir. Okul Öncesi Eğitimi çalışma alanı tüm disiplin alanlarına ait çalışma alanları arasında en fazla makalenin yayınlandığı çalışma alanını oluşturmaktadır ve oranının \%26,83 (11) olduğu görülmektedir. Eğitim Bilimleri disiplin alanında yer alan diğer çalışma alanlarına ait makale yayınlanma oranlarının sırasıyla PDR \%12,2 (5); Eğitim Bilimleri 
\%7,31 (3) ve Özel Eğitim \%2,44 (1) olduğu görülmektedir. Sağlık Bilimleri disiplin alanında "Hemşirelik", ve "Beslenme ve Diyetetik" çalışma alanlarında makalelerin yayınlandığı görülmektedir. Sağlık Bilimleri disiplin alanında yer alan çalışma alanlarına ait makale yayınlanma oranlarının sırasıyla Hemşirelik \%12,2 (5); Beslenme ve Diyetetik ve Çocuk Gelişimi \%2,44 (1) olduğu görülmektedir. Tıp Bilimleri disiplin alanında "Pediatri", "Ruh Sağlığı ve Hastalıkları" ve "Psikiyatri" çalışma alanlarında makalelerin yayınlandığı görülmektedir. Tıp Bilimleri disiplin alanında yer alan çalışma alanlarına ait makale yayınlanma oranlarının sırasıyla Psikiyatri \%14,63 (6); Pediatri ve Ruh Sağlığı Hastalıkları \%2,44 (1) olduğu görülmektedir.

Tablo 7. Duygusal ve Davranışsal Problemlere İlişkin Ebeveyn Tutumunu İnceleyen Makalelerin Araştırma Yöntemlerine Göre Dă̆ılımı

\begin{tabular}{lll}
\hline Araştırma Yöntemi & Frekans (f) & Yüzdelik (\%) \\
\hline Nicel & 40 & 97,56 \\
Nitel & 1 & 2,44 \\
Toplam & 41 & 100,0 \\
\hline
\end{tabular}

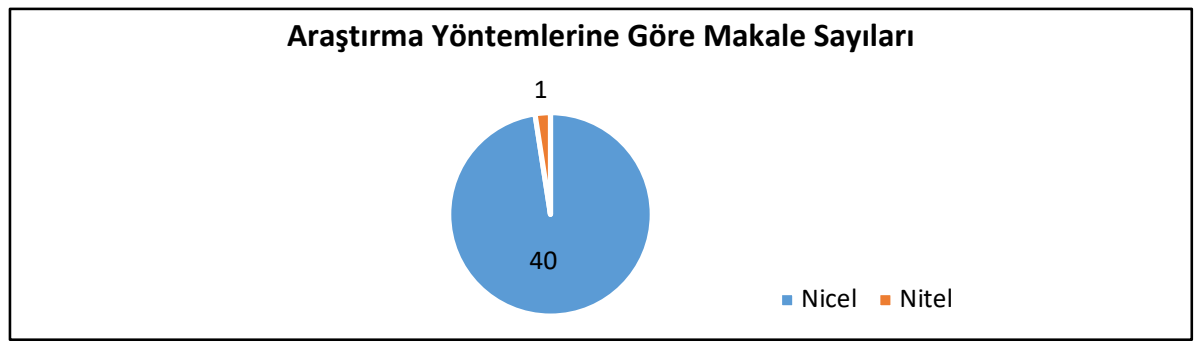

Şekil 5. Duygusal ve Davranışsal Problemlere İlişkin Ebeveyn Tutumunu İnceleyen Makalelerin Araştırma Yöntemlerine Göre Dă̆ılımı

Tablo 7 ve Şekil 5'te; 2005-2020 yılları arasında duygusal ve davranışsal problemlere ilişkin ebeveyn tutumunu inceleyen makalelerin araştırma yöntemlerine göre dağılımı görülmektedir. Makalelerin yöntemleri incelendiğinde, en fazla kullanılan araştırma yönteminin nicel araştırma yöntemi olduğu görülmektedir. Nicel araştırma yöntemiyle oluşturulan makaleler, incelenen makalelerin \%97,62'sini (40) oluşturmaktadır. Nitel araştırma yöntemiyle oluşturulan makaleler ise incelenen makalelerin $\% 2,38$ 'ini (1) oluşturmaktadır. 
Tablo 8. Duygusal ve Davranışsal Problemlere İlişkin Ebeveyn Tutumunu İnceleyen Makalelerin İncelenen Yaş Gruplarına Göre Dağılımı

\begin{tabular}{lll}
\hline Yaş Grupları & Frekans (f) & Yüzdelik (\%) \\
\hline Ergenlik Dönemi (13-18 Yaş Aralığı) & 20 & 48,78 \\
Okul Öncesi Dönem (0-6 Yaş Aralığı) & 17 & 41,46 \\
İlkokul Dönemi (7-12 Yaş Aralığı) & 4 & 9,76 \\
Toplam & 41 & 100,0 \\
\hline
\end{tabular}

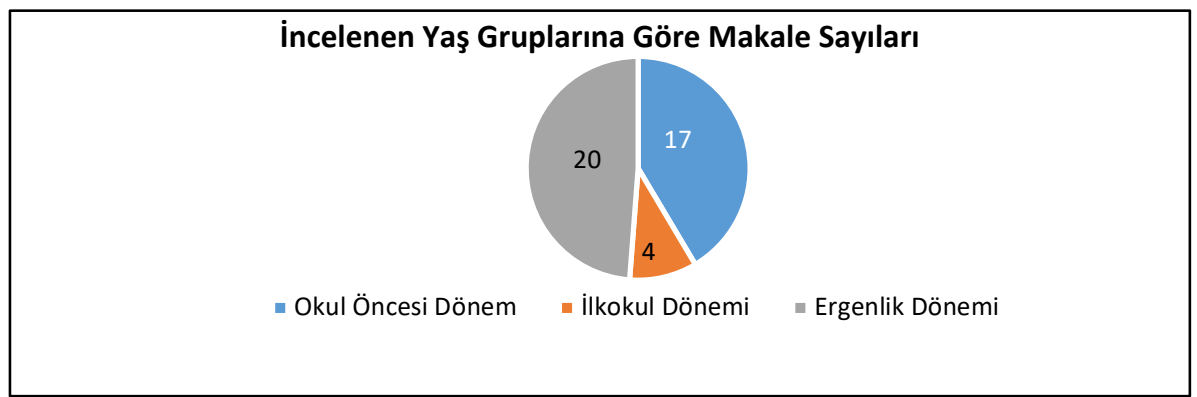

Şekil 6. Duygusal ve Davranışsal Problemlere İlişkin Ebeveyn Tutumunu İnceleyen Makalelerin İncelenen Yaş Gruplarına Göre Dağılımı

Tablo 8 ve Şekil 6'da; 2005-2020 yılları arasında duygusal ve davranışsal problemlere ilişkin ebeveyn tutumunu inceleyen makalelerin yaş gruplarına göre dağılımı görülmektedir. Makalelerin örneklem gruplarını oluşturan yaş grupları incelendiğinde, makalelerde en fazla incelenen yaş grubunun ergenlik dönemi (13-18 yaş aralı̆̆ı) olduğu görülmektedir. Örneklemi ergenlik dönemindeki çocuklar olan makaleler, incelenen makalelerin \%48,78'ini (20) oluşturduğu görülmektedir. Diğer yaş grupları ile örneklem oluşturulan makalelerin dağılım oranlarının sırasıyla okul öncesi dönem \%41,46 (17) ve ilkokul dönemi \%9,76 (4) olduğu görülmektedir. 
Tablo 9. Duygusal ve Davranışsal Problemlere İlişkin Ebeveyn Tutumunu İnceleyen Makalelerin Kullanılan Ebeveyn Tutum Ölçeklerine Göre Dağılımı

\begin{tabular}{lll}
\hline Ölçekler & Frekans (f) & Yüzdelik (\%) \\
\hline Ebeveyn Tutum Ölçeği (ETÖ) & 10 & 24,39 \\
Aile Hayatı ve Çocuk Yetiştirme Tutumu Ölçeği & 10 & 24,39 \\
(AHÇYTÖ) & 9 & 21,95 \\
Ana-Baba Tutum Ölçeği (ABTÖ) & 3 & 7,32 \\
Aile Değerlendirme Ölçeği (ADÖ) & 2 & 4,88 \\
Ebeveyn Kabul-Red/Kontrol Ölçeği (EKRÖ) & 2 & 4,88 \\
Çocuk Yetiştirme Stilleri Ölçeği (ÇYSÖ) & 1 & 2,43 \\
Anne-Babalık Stilleri ve Boyutları Ölçeği (ABSBÖ) & 4 & 9,76 \\
Ölçme aracı belirtilmemiş & 41 & 100,0 \\
Toplam & & \\
\hline
\end{tabular}

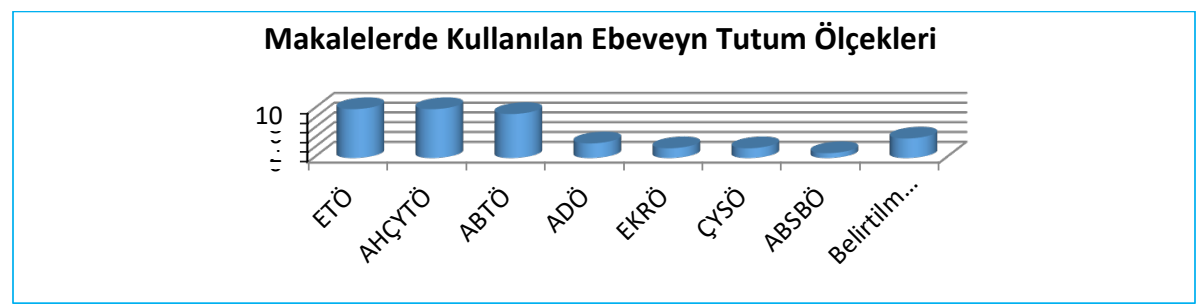

Şekil 7. Duygusal ve Davranışsal Problemlere İlişkin Ebeveyn Tutumunu İnceleyen Makalelerin Kullanılan Ebeveyn Tutum Ölçeklerine Göre Dağılımı

Tablo 9 ve Şekil 7'de; 2005-2020 yılları arasında duygusal ve davranışsal problemlere ilişkin ebeveyn tutumunu inceleyen makalelerde kullanılan ebeveyn tutum ölçeklerinin dağılımı görülmektedir. Makalelerdeki ebeveyn tutum ölçekleri incelendiğinde, en fazla kullanılan ölçeklerin Ebeveyn Tutum Ölçeği (ETÖ) ve Aile Hayatı ve Çocuk Yetiştirme Tutumu Ölçeği (AHÇYTÖ) olduğu görülmektedir. ETÖ ve AHÇYTÖ kullanılan makaleler, incelenen makalelerin \%48,78'ini (10) oluşturmaktadır. Diğer ebeveyn tutum ölçeklerinin incelenen makalelerdeki dağılım oranlarına bakıldığında, sırasıyla Ana-Baba Tutum Ölçeği (ABTÖ) \%21,95 (9); Aile Değerlendirme Ölçeği (ADÖ) \%7,32 (3); Ebeveyn Kabul-Red/Kontrol Ölçeği (EKRÖ) ve Çocuk Yetiştirme Stilleri Ölçeği (ÇYSÖ) \%4,88 (2) ve Anne-Babalık Stilleri ve Boyutları Ölçeği (ABSBÖ) \%2,43 (1) olduğu görülmektedir. Ayrıca ölçme aracı belirtilmeyen makalelerin incelenen tüm makaleler içerisindeki oranının \%9,76 (4) olduğu belirlenmiştir. 
Aysel Çoban- Zehra Bilgen- Özge İdrisoğlu- İlyas Sönmez- Hatice Berna Türe Köse Hatice Ünlü Bozkurt

Tablo 10. Duygusal ve Davranıssal Problem Türlerine Göre Kullanılan Ölçme Araçları

\begin{tabular}{|c|c|}
\hline DDP Türü & Ölçek \\
\hline $\begin{array}{l}\text { Davranım Bo- } \\
\text { zukluğu }\end{array}$ & $\begin{array}{l}\text { Çocuk Davranış Değerlendirme Ölçeği-Ebeveyn Formu (ÇDDÖ/2-3 yaş ve 4-18 yaş } \\
\text { formları) } \\
\text { Akran Şiddeti Uygulama Ölçeği } \\
\text { Okul Öncesi Davranış Sorunları Tarama Ölçeği (OÖDSTÖ) } \\
\text { Okul Öncesi Sosyal Davranış Ölçeği-Öğretmen Formu (OÖSDÖ-ÖF) } \\
\text { Çocukluk Çağı Travmaları Ölçeği (ÇÇTÖ) } \\
\text { Akran Zorbalarını Belirleme Ölçeği } \\
6 \text {-18 Yaş Çocuk ve Gençler için Davranış Değerlendirme Ölçeği-ÇDDÖ/6-18 } \\
\text { Araştırmacı Tarafından Hazırlanan Form* } \\
\text { Sosyal Yetkinlik ve Davranış Değerlendirme-30 (SYDD-30) } \\
\text { Ladd ve Profilet Çocuk Davranış Ölçeği } \\
\text { Çocuk Saldırganlık Ölçeği } \\
\text { Kısa Semptomlar Envanteri (KSE) } \\
\text { Saldırganlık Ölçeği (Aggression Questionnaire) } \\
\text { Şiddet Eğilim Ölçeği (ŞEÖ) } \\
\text { Güçler ve Güçlükler Anketi (GGA) (Strenghts and Difficulties Questionarie-SDQ } \\
\text { Öğrenci İlişkileri Tutum Ölçeği } \\
\text { Kısa Semptom Envanteri (KSE) } \\
\text { Saldırganlık Yönelim Ölçeği } \\
\text { 11-18 Yaş grubu Gençler İçin Kendini Değerlendirme Ölçeği (YSR) } \\
\text { Çatışma Çözme Davranış Ölçeği }\end{array}$ \\
\hline $\begin{array}{l}\text { Karşı Gelme Bo- } \\
\text { zukluğu }\end{array}$ & $\begin{array}{l}\text { Çocuk Davranış Değerlendirme Ölçeği-Ebeveyn Formu (ÇDDÖ/2-3 yaş ve 4-18 yaş } \\
\text { formları) } \\
\text { 6-18 Yaş Çocuk ve Gençler için Davranış Değerlendirme Ölçeği-ÇDDÖ/6-18 } \\
\text { Araştırmacı Tarafından Hazırlanan Form* }\end{array}$ \\
\hline $\begin{array}{l}\text { Kaygı Bo- } \\
\text { zukluğu }\end{array}$ & $\begin{array}{l}\text { Kaygı Duyarlığı İndeksi - Düzeltilmiş } \\
\text { 6-18 Yaş Çocuk ve Gençler için Davranış Değerlendirme Ölçeği-ÇDDÖ/6-18 } \\
\text { Okul Öncesi Davranış Sorunları Tarama Ölçeği (OÖDSTÖ) } \\
\text { Araştırmacı Tarafından Hazırlanan Form* } \\
\text { Kısa Semptomlar Envanteri (KSE) } \\
\text { Erişkin Ayrılma Anksiyetesi Ölçeği } \\
\text { Alışkı Sorunları Belirleme Bilgi Formu**** }\end{array}$ \\
\hline $\begin{array}{l}\text { Yeme Bo- } \\
\text { zuklukları }\end{array}$ & $\begin{array}{l}\text { Riskli Davranışlar Ölçeği (RDÖ) } \\
\text { Çocuklarda Yeme Davranışı Anketi (ÇYDA) }\end{array}$ \\
\hline $\begin{array}{l}\text { Depresif Bo- } \\
\text { zukluklar }\end{array}$ & $\begin{array}{l}\text { Çocuk Davranış Değerlendirme Ölçeği-Ebeveyn Formu (ÇDDÖ/2-3 yaş ve 4-18 yaş } \\
\text { formları) } \\
6-18 \text { Yaş Çocuk ve Gençler için Davranış Değerlendirme Ölçeği-ÇDDÖ/6-18 } \\
\text { Araştırmacı Tarafından Hazırlanan Form* } \\
\text { Sosyal Yetkinlik ve Davranış Değerlendirme-30 (SYDD-30) } \\
\text { Kısa Semptomlar Envanteri (KSE) } \\
\text { Çocuklar İçin Depresyon Ölçeği (ÇDÖ) } \\
\text { Stresle Bașaçıkma Tutumları Envanteri (SBTE) } \\
\text { 11-18 Yaş grubu Gençler İçin Kendini Değerlendirme Ölçeği (YSR) }\end{array}$ \\
\hline $\begin{array}{l}\text { Duygusal Prob- } \\
\text { lemler }\end{array}$ & $\begin{array}{l}\text { Riskli Davranışlar Ölçeği (RDÖ) } \\
\text { Güçler ve Güçlükler Anketi (GGA) (Strenghts and Difficulties Questionarie-SDQ) } \\
\text { Kısa Semptomlar Envanteri (KSE) } \\
\text { Marmara Sosyal Duygusal Uyum Ölçeği (MASDU-5 Yaş) }\end{array}$ \\
\hline $\begin{array}{l}\text { İletişim Bo- } \\
\text { zuklukları }\end{array}$ & Araştırmacı Tarafından Hazırlanan Form* \\
\hline
\end{tabular}


Karşılaşılan Duygusal ve Davranışsal Problemlerin Ebeveyn Tutumu ile İlişkisinin İncelenmesi: İçerik Analizi

\begin{tabular}{|c|c|}
\hline $\begin{array}{l}\text { Dışa Atım Bo- } \\
\text { zuklukları }\end{array}$ & $\begin{array}{l}\text { Araştırmacı Tarafından Hazırlanan Form* } \\
\text { Araştırmacı Tarafından Hazırlanan Anket Formu } \\
\text { Alşsı Sorunları Belirleme Bilgi Formu }\end{array}$ \\
\hline $\begin{array}{l}\text { Anti Sosyal } \\
\text { Kişilik Bo- } \\
\text { zukluğu }\end{array}$ & Riskli Davranışlar Ölçeği (RDÖ) \\
\hline $\begin{array}{l}\text { Madde Kullanım } \\
\text { Bozukluğu }\end{array}$ & Riskli Davranışlar Ölçeği (RDÖ) \\
\hline DEHB & $\begin{array}{l}\text { Çocuk Davranış Değerlendirme Ölçeği-Ebeveyn Formu (ÇDDÖ/2-3 yaş ve 4-18 yaş } \\
\text { formları) } \\
\text { Conners Öğretmen Derecelendirme Ölçeği (CÖDÖ, Conners' Teacher Rating Scale, } \\
\text { CTRS-28) } \\
\text { Conners Anababa Derecelendirme Ölçeği (CADÖ, Conners' Parent Rating Scale, } \\
\text { CPRS-48) } \\
\text { Okul Çağı Çocukları İçin Duygulanım Bozuklukları ve Şizofreni Görüşme Çizelgesi- } \\
\text { Şimdi ve Yaşam Boyu Versiyonu Türkçe Uyarlaması (ÇDŞG-ŞY) } \\
\text { Okul Öncesi Davranış Sorunları Tarama Ölçeği (OÖDSTÖ) } \\
\text { 6-18 Yaş Çocuk ve Gençler için Davranış Değerlendirme Ölçeği-ÇDDÖ/6-18 } \\
\text { Araştırmacı Tarafından Hazırlanan Form* } \\
\text { Güçler ve Güçlükler Anketi (GGA) (Strenghts and Difficulties Questionarie-SDQ) } \\
\text { 11-18 Yaş grubu Gençler İçin Kendini Değerlendirme Ölçeği (YSR) }\end{array}$ \\
\hline $\begin{array}{l}\text { Sosyal Uyum } \\
\text { Bozukluğu }\end{array}$ & $\begin{array}{l}\text { Çocuk Davranış Değerlendirme Ölçeği-Ebeveyn Formu (ÇDDÖ/2-3 yaş ve 4-18 yaş } \\
\text { formları) } \\
\text { Araştırmacı Tarafından Hazırlanan Form* } \\
\text { Uyum Sorununu Belirleme Formu ** } \\
\text { Sosyal Yetkinlik ve Davranış Değerlendirme-30 (SYDD-30) } \\
\text { Güçler ve Güçlükler Anketi (GGA) (Strenghts and Difficulties Questionarie-SDQ) } \\
\text { 11-18 Yaş grubu Gençler İçin Kendini Değerlendirme Ölçeği (YSR) }\end{array}$ \\
\hline $\begin{array}{l}\text { İnternet } \\
\text { Bağımlllığ } \\
\end{array}$ & İnternet Bağımlılık Ölçeği (IВÖ) \\
\hline $\begin{array}{l}\text { Uyku Bo- } \\
\text { zuklukları }\end{array}$ & $\begin{array}{l}\text { Çocuk Davranış Değerlendirme Ölçeği-Ebeveyn Formu (ÇDDÖ/2-3 yaş ve 4-18 yaş } \\
\text { formları) } \\
\text { Araştırmacı Tarafından Hazırlanan Form* }\end{array}$ \\
\hline Somatizasyon & $\begin{array}{l}\text { Çocuk Davranış Değerlendirme Ölçeği-Ebeveyn Formu (ÇDDÖ/2-3 yaş ve 4-18 yaş } \\
\text { formları) } \\
\text { Kısa Semptomlar Envanteri (KSE) } \\
\text { 11-18 Yaş grubu Gençler İçin Kendini Değerlendirme Ölçeği (YSR) } \\
\text { Çocuk Somatizasyon Envanteri-24 (ÇSE-24) }\end{array}$ \\
\hline \multicolumn{2}{|c|}{ 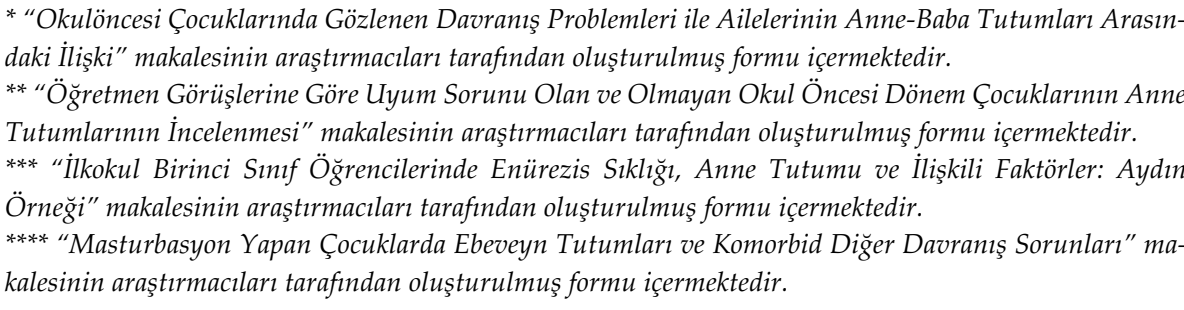 } \\
\hline
\end{tabular}

Tablo 10'a göre; duygusal davranışsal problem türlerinden davranım bozukluğunu tespit etmek amacıyla 20 farklı ölçme aracı kullanılmıştır. Bu ölçme araçlarından bazıları "Akran Şiddeti Uygulama Ölçeği”, "Çocuk 
Saldırganlık Ölçeği”, "Şiddet Eğilim Ölçeği (ŞEÖ)” olarak belirlenmiştir. Karşı gelme bozukluğunu tespit etmek için 3 farklı ölçme aracı kullanılmıştır. Bu ölçme araçlarından bazıları "Çocuk Davranış Değerlendirme Ölçeği-Ebeveyn Formu (ÇDDÖ/2-3 yaş ve 4-18 yaş formları)", "6-18 Yaş Çocuk ve Gençler için Davranış Değerlendirme Ölçeği-ÇDDÖ/6-18” olarak belirlenmiştir. Kaygı bozukluğunu tespit etmek için yedi farklı ölçme aracı kullanılmıştır. Bu ölçme araçlarından bazıları "Kaygı Duyarlığı İndeksi - Düzeltilmiş", "Kısa Semptomlar Envanteri (KSE)”, "Erişkin Ayrılma Anksiyetesi Ölçeği" olarak belirlenmiştir. Yeme bozukluğunu tespit etmek için iki farklı ölçme aracı kullanılmıştır. Bu ölçme araçları "Riskli Davranışlar Ölçeği (RDÖ)" ve "Çocuklarda Yeme Davranışı Anketi (ÇYDA)" olarak belirlenmiştir. Depresif bozuklukları tespit etmek için sekiz farklı ölçme aracı kullanılmıştır. Bu ölçme araçlarından bazıları "Kısa Semptomlar Envanteri (KSE)", "Çocuklar İçin Depresyon Ölçeği (ÇDÖ)”, "Stresle Başaçıkma Tutumları Envanteri (SBTE)" olarak belirlenmiştir. Duygusal rahatsızlıkları tespit etmek için dört farklı ölçme aracı kullanılmıştır. Bu ölçme araçlarından bazıları "Riskli Davranışlar Ölçeği (RDÖ)", "Kısa Semptomlar Envanteri (KSE)", "Güçler ve Güçlükler Anketi (GGA)" olarak belirlenmiştir. İletişim bozukluklarını tespit etmek için bir ölçme aracı kullanılmıştır. Bu ölçme aracı makalenin yazarları tarafından oluşturulmuş form olarak belirlenmiştir. Dışa atım bozukluklarını tespit etmek için üç farklı ölçme aracı kullanılmıştır. Bu ölçme araçları makalelerin yazarları tarafından oluşturulmuş formlar olarak belirlenmiştir. Anti sosyal kişilik bozukluğu ve madde kullanım bozukluğunu tespit etmek için bir ölçme aracı kullanılmıştır. Bu ölçme aracı "Riskli Davranışlar Ölçeği (RDÖ)" olarak belirlenmiştir. Dikkat eksikliği ve hiperaktivite bozukluğunu tespit etmek için dokuz farklı ölçme aracı kullanılmıştır. Bu ölçme araçlarından bazıları "Çocuk Davranış Değerlendirme Ölçeği-Ebeveyn Formu (ÇDDÖ/2-3 yaş ve 4-18 yaş formları)", "Conners Anababa Derecelendirme Ölçeği (CADÖ)”, "Güçler ve Güçlükler Anketi (GGA)” olarak belirlenmiştir. Sosyal uyum bozukluğunu tespit etmek için altı farklı ölçme aracı kullanılmıştır. Bu ölçme araçlarından bazıları "Sosyal Yetkinlik ve Davranış Değerlendirme-30 (SYDD-30)”, “Güçler ve Güçlükler Anketi (GGA)”, "11-18 Yaş Grubu Gençler İçin Kendini Değerlendirme Ölçeği (YSR)" olarak belirlenmiştir. İnternet bağımlılığını tespit etmek için bir ölçme aracı kullanılmıştır. Bu ölçme aracı “İnternet Bağımlılık Ölçeği 
Karşılaşılan Duygusal ve Davranışsal Problemlerin Ebeveyn Tutumu ile İlişkisinin İncelenmesi: İçerik Analizi

(IBÖ)" olarak belirlenmiştir. Uyku bozukluklarını tespit etmek için iki farklı ölçme aracı kullanılmıştır. Bu ölçme araçları "Çocuk Davranış Değerlendirme Ölçeği-Ebeveyn Formu (ÇDDÖ/2-3 yaş ve 4-18 yaş formları)" ve makalenin yazarları tarafından oluşturulmuş form olarak belirlenmiştir. Somatizasyonu tespit etmek için dört farklı ölçme aracı kullanılmıştır. Bu ölçme araçlarından bazıları "11-18 Yaş Grubu Gençler İçin Kendini Değerlendirme Ölçeği (YSR)”, "Kısa Semptomlar Envanteri (KSE)”, “Çocuk Somatizasyon Envanteri-24 (ÇSE-24)" olarak belirlenmiştir.

Tablo 11. Duygusal ve Davranışsal Problemlere İlişkin Incelenen Makalelerin Ebeveyn Tutumuna Yönelik Sonuçları

\begin{tabular}{|c|c|c|}
\hline $\begin{array}{l}\text { Makale } \\
\text { Numarası }\end{array}$ & Yaş Grubu & $\begin{array}{l}\text { Duygusal ve Davranışsal Problemler ile Ebeveyn Tutumuna Yönelik So- } \\
\text { nuçlar }\end{array}$ \\
\hline $\begin{array}{l}\text { Makale } \\
\# 1\end{array}$ & İ. O. D. (7-12) & $\begin{array}{l}\text { Sıcaklık-sevgi, düşmanlık-saldırganlık, kayıtsızlık-ihmal, farklılaşmamış red, } \\
\text { kontrol olarak ele alınan ebeveyn tutumlarının bütün bir model olarak soma- } \\
\text { tizasyon belirtilerini açıklamada istatistiksel olarak anlamlı olduğu sonucuna } \\
\text { ulaşılmıştır. Buna göre; çocukların babalarından ne kadar çok düşmanlık al- } \\
\text { gılarlarsa o kadar sık somatik belirti gösterdikleri ortaya konmuştur. Ayrıca, } \\
\text { anneye ilişkin algılanan kabul-red, kontrol düzeylerinin bütün bir model ola- } \\
\text { rak somatizasyon üzerinde anlamlı etkiye sahip olduğu görülmüştür. }\end{array}$ \\
\hline $\begin{array}{l}\text { Makale } \\
\# 2\end{array}$ & E. D. $(13-18)$ & $\begin{array}{l}\text { Anne baba tutumu ile zorbalık mağduru olma ve zorbalık davranışı gösterme } \\
\text { durumu arasında anlamlı bir ilişki bulunmamıştır. }\end{array}$ \\
\hline $\begin{array}{l}\text { Makale } \\
\# 3\end{array}$ & O. Ö. D. (0-6) & $\begin{array}{l}\text { OSB tanısı olan çocuğa sahip ebeveynlerin yüksek düzeyde başarı odaklı ve } \\
\text { yönlendirici etkileşim özelliklerine sahip oldukları, yeterince duyarlı-yanıtla- } \\
\text { yıcı olamadıkları; annelerin, babalara oranla daha fazla duyarlı-yanıtlayıcı et- } \\
\text { kileşim davranışları sergiledikleri görülmüştür. }\end{array}$ \\
\hline $\begin{array}{l}\text { Makale } \\
\# 4\end{array}$ & O. Ö. D. (0-6) & $\begin{array}{l}\text { Öğretmen görüşlerine göre uyum sorunu olan erkek çocukların annelerinin } \\
\text { otoriter tutum puanlarının kız çocuk sahibi annelerin puanından yüksek ol- } \\
\text { duğu belirlenmiştir. Anne ve baba öğrenim düzeyleri incelendiğinde; uyum } \\
\text { sorunu olan çocuklarda üniversite ve üzeri mezunu olan anneler daha düşük } \\
\text { aşırı koruyucu tutum puan ortalamasına sahip olduğu görülmüştür. Uyum } \\
\text { sorunu olan çocuklarda babası üniversite ve üzeri mezunu olan çocukların } \\
\text { anneleri daha yüksek otoriter tutum puan ortalamasına; babası ilköğretim } \\
\text { mezunu olan çocukların anneleri ise daha yüksek aşırı koruyucu tutum pua- } \\
\text { nına sahiptir. }\end{array}$ \\
\hline $\begin{array}{l}\text { Makale } \\
\# 5\end{array}$ & O. Ö. D. (0-6) & $\begin{array}{l}\text { Demokratik ebeveyn tutumu ile yetiştirilen çocukların okul ortamındaki sos- } \\
\text { yal duygusal uyumları yüksek bulunurken; otoriter, aşırı koruyucu ve izin } \\
\text { verici ebeveyn tutumuyla yetişen çocukların okul ortamındaki sosyal duygu- } \\
\text { sal uyumlarının düşük olduğu görülmüştür. }\end{array}$ \\
\hline $\begin{array}{l}\text { Makale } \\
\# 6\end{array}$ & E. D. (13-18) & $\begin{array}{l}\text { Ebeveyn tutumunda baskı-disiplinin reddi ve arkadaşça-eşit-paylaşımcı } \\
\text { ebeveyn çocuk ilişkisi istemi, ergenler tarafından belirtilen dışa yönelim prob- } \\
\text { lem davranışlarıyla bağlantılı olduğu görülmüştür. }\end{array}$ \\
\hline $\begin{array}{l}\text { Makale } \\
\# 7\end{array}$ & E. D. $(13-18)$ & $\begin{array}{l}\text { DEHB tanılı çocuklar ana babalarını daha reddedici ve denetlemesi az olarak } \\
\text { algılarken, annelerin daha sıkı disiplin uygulayan ve daha az demokratik tu- } \\
\text { tum bildirdiği saptanmıştır. }\end{array}$ \\
\hline $\begin{array}{l}\text { Makale } \\
\# 8\end{array}$ & O. Ö. D. (0-6) & $\begin{array}{l}\text { Ebeveyni baskıcı tutuma sahip çocukların akran şiddetine maruz kalma ve } \\
\text { akran şiddeti uygulama düzeyleri daha yüksek bulunmuştur. }\end{array}$ \\
\hline
\end{tabular}




\begin{tabular}{|c|c|c|}
\hline $\begin{array}{l}\text { Makale } \\
\# 9\end{array}$ & O. Ö. D. (0-6) & $\begin{array}{l}\text { Çalışma sonucunda annelerin çocuklarının beslenmesinde baskıcı bir tutum } \\
\text { izledikleri görülmüştür. }\end{array}$ \\
\hline $\begin{array}{l}\text { Makale } \\
\# 10\end{array}$ & O. Ö. D. (0-6) & $\begin{array}{l}\text { Çocuk psikiyatrisine başvuran annelerin; aşırı koruyuculuk, katı disiplin, } \\
\text { karı-koca geçimsizliği ve evkadınlığı rolünün reddi alt boyutlarından daha } \\
\text { yüksek ortalama aldıkları görülmüştür. Karı-koca geçimsizliği, katı disiplin } \\
\text { ve ev kadınlığı reddi ile çocuktaki dışa yönelim davranışları ilişkili; çocuk içe } \\
\text { yönelim davranışları ile geçimsizlik ve aşırı koruyuculuk ilişkili bulun- } \\
\text { muştur. }\end{array}$ \\
\hline $\begin{array}{l}\text { Makale } \\
\# 11\end{array}$ & O. Ö. D. (0-6) & $\begin{array}{l}\text { Otoriter ve izin verici anne tutumlarının, 5-6 yaş çocuklarındaki saldırganlık } \\
\text { ve akran şiddetine maruz kalma düzeyleri ile olumlu yönde; olumlu sosyal } \\
\text { davranış düzeyleri ile olumsuz yönde anlamlı düzeyde ilişkili olduğu belir- } \\
\text { lenmiştir. Yetkeci/demokratik anne tutumunda ise çocukların saldırganlık ve } \\
\text { akran şiddetine maruz kalma düzeyleri ile olumsuz yönde; olumlu sosyal } \\
\text { davranışları ile olumlu yönde anlamlı düzeyde ilişkili bulunmuştur. }\end{array}$ \\
\hline $\begin{array}{l}\text { Makale } \\
\# 12\end{array}$ & İ. O. D. (7-12) & $\begin{array}{l}\text { Çalışma sonucunda ilköğretim çağındaki öğrencilerin saldırganlık düzeyle- } \\
\text { rinin anne baba kavga etme sıklığı ve ana-baba tutumu gibi değişkenlerden } \\
\text { etkilendiği ve anne-babası otoriter davranan öğrencilerin saldırganlık pu- } \\
\text { anlarının daha yüksek olduğu bulunmuştur. }\end{array}$ \\
\hline $\begin{array}{l}\text { Makale } \\
\# 13\end{array}$ & E. D. $(13-18)$ & $\begin{array}{l}\text { DEHB'li çocukları tarafından izin verici-ihmalkâr ya da otoriter olarak al- } \\
\text { gılanan ebeveynlerin evlilik uyumlarının daha düşük olduğu, izin verici- } \\
\text { hoşgörülü olarak algılanan ebeveynlerin ise evlilik uyumlarının daha yüksek } \\
\text { olduğu sonucuna ulaşılmıştır. Ebeveyn tutumlarının ve evlilik uyumlarının } \\
\text { çocuklarda DEHB için bir risk faktörü olduğu sonucuna varılmıştır. }\end{array}$ \\
\hline $\begin{array}{l}\text { Makale } \\
\# 14\end{array}$ & E. D. $(13-18)$ & $\begin{array}{l}\text { DEHB olan ergenlerin ebeveynlerinin daha çok ev kadınlığını reddettiği, } \\
\text { daha çok karı-koca geçimsizliği yaşadığı ve daha fazla baskı-disiplin uygu- } \\
\text { ladığı saptanmıştır. }\end{array}$ \\
\hline $\begin{array}{l}\text { Makale } \\
\# 15\end{array}$ & O. Ö. D. (0-6) & $\begin{array}{l}\text { Yetişkin ayrılık kaygısı ile demokratik ebeveynlik tutumu arasında negatif, } \\
\text { otoriter, izin verici ve aşırı koruyucu tutum arasında ise pozitif bir ilişki } \\
\text { olduğu görülmüştür. }\end{array}$ \\
\hline $\begin{array}{l}\text { Makale } \\
\# 16\end{array}$ & O. Ö. D. (0-6) & $\begin{array}{l}\text { Çalışmanın sonucunda, ebeveyn tutumlarının çocukların okula hazır bulu- } \\
\text { nuşluğunu doğrudan veya öz-düzenleme becerileri aracılığıyla dolaylı olarak } \\
\text { yordamadığı belirlenmiştir. }\end{array}$ \\
\hline $\begin{array}{l}\text { Makale } \\
\# 17\end{array}$ & E. D. $(13-18)$ & $\begin{array}{l}\text { Çalışmanın sonucunda aşırı koruyucu annelik ve ev kadınlığı rolünü } \\
\text { reddetme tutumları, dışsallaştırma bozukluklarında, içselleştirme bo- } \\
\text { zukluklarına göre daha yüksek olarak saptanmıştır. }\end{array}$ \\
\hline $\begin{array}{l}\text { Makale } \\
\# 18\end{array}$ & E. D. $(13-18)$ & $\begin{array}{l}\text { Çalışmanın sonucunda anne baba tutumlarının, ergenlerin çatışma çözme } \\
\text { davranışını yordadığı belirlenmiştir. Demokratik anne baba tutumları ile } \\
\text { saldırganlık arasında negatif bir ilişki; koruyucu ve otoriter anne baba tu- } \\
\text { tumları ile saldırganlık arasında pozitif bir ilişki olduğu görülmüştür. Ayrıca, } \\
\text { demokratik anne baba tutumları ile çatışma çözme davranışının problem } \\
\text { çözme alt boyutu arasında olumlu bir ilişki saptanmıştır. Otoriter anne baba } \\
\text { tutumları ile çatışma çözmenin problem çözme alt boyutu arasında olumsuz } \\
\text { bir ilişki ortaya çıkmıştır. }\end{array}$ \\
\hline $\begin{array}{l}\text { Makale } \\
\# 19\end{array}$ & E. D. $(13-18)$ & $\begin{array}{l}\text { Demokratik ebeveyn tutumu ile kaygı tutarlı̆̆ı arasında negatif yönde bir } \\
\text { ilişki bulunurken; koruyucu-istekçi ebeveyn tutumu ve otoriter ebeveyn tu- } \\
\text { tumunun kaygı duyarlığını önemli yordayıcıları olduğu sonucuna } \\
\text { ulaşılmıştır. }\end{array}$ \\
\hline $\begin{array}{l}\text { Makale } \\
\# 20\end{array}$ & E. D. $(13-18)$ & $\begin{array}{l}\text { Problem davranışlar üzerinde ilgisiz anne-baba tutumunun etkili olduğu; } \\
\text { psikolojik belirtiler üzerinde ise otoriter anne-baba tutumunun daha etkili } \\
\text { olduğu bulunmuştur. Ayrıca, demokratik aile ortamlarında yetişen ergen- } \\
\text { lerin diğer anne-baba tutumlarına sahip akranlarına göre daha az problem } \\
\text { davranışlar sergiledikleri görülmüştür. }\end{array}$ \\
\hline
\end{tabular}


Karşılaşılan Duygusal ve Davranışsal Problemlerin Ebeveyn Tutumu ile İlişkisinin İncelenmesi: İçerik Analizi

\begin{tabular}{|c|c|c|}
\hline $\begin{array}{l}\text { Makale } \\
\# 21\end{array}$ & E. D. $(13-18)$ & $\begin{array}{l}\text { Algılanan ana baba tutumlarının kabul/ilgi ve psikolojik özerklik boyut- } \\
\text { larının saldırganlığın anlamlı birer yordayıcısı olduğu tespit edilmiştir. }\end{array}$ \\
\hline $\begin{array}{l}\text { Makale } \\
\text { \#22 }\end{array}$ & İ. O. D. (7-12) & $\begin{array}{l}\text { Anne baba tutumları ergenlerin saldırganlık ve sosyal beceri puanlarını an- } \\
\text { lamlı düzeyde yordamıştır. Anne baba tutumları ile saldırganlık, olumsuz } \\
\text { sosyal davranıs, ve olumlu sosyal davranıs, puanları arasında anlamlı ilişki } \\
\text { oldugu görülmüş; anne baba tutumları, saldırganlıktaki varyansın } \% 21^{\prime} i n i \text {, } \\
\text { olumsuz sosyal davranıstaki varyansın \%10'unu ve olumlu sosyal dav- } \\
\text { ranıstaki varyansın \%5'ini açıkladığı belirlenmiştir. }\end{array}$ \\
\hline $\begin{array}{l}\text { Makale } \\
\# 23\end{array}$ & E. D. $(13-18)$ & $\begin{array}{l}\text { Ergenlerin arkadaş bağlılığı puan ortalamalarının, algılanan ebeveyn tu- } \\
\text { tumlarına göre anlamlı bir biçimde farklılık gösterdiği saptanmıştır. Ebeveyn } \\
\text { tutumunu "ilgisiz" olarak algılayan ergenlerin arkadaş bağlılığı ve internet } \\
\text { bağımlılığı puan ortalamalarının "koruyucu", "otoriter" ve "demokratik" } \\
\text { olarak algılayanlardan anlamlı düzeyde yüksek olduğu bulunmuştur. }\end{array}$ \\
\hline $\begin{array}{l}\text { Makale } \\
\# 24\end{array}$ & E. D. $(13-18)$ & $\begin{array}{l}\text { Ergenlerin algıladıkları anne-baba tutumlarına göre anksiyete, depresyon, } \\
\text { olumsuz benlik, somatizasyon, hostilite ve toplam belirti puan ortalama- } \\
\text { larının istatistiksel olarak anlamlı bir biçimde farklılaştığı belirlenmiştir. } \\
\text { Anne-baba tutumunu demokratik ve koruyucu-istekçi olarak algılayan } \\
\text { ergenlerin psikolojik belirtilerinin anne-baba tutumunu otoriter ve reddedici- } \\
\text { ilgisiz-tutarsız olarak algılayan öğrencilerden daha düşük olduğu görül- } \\
\text { müştür. }\end{array}$ \\
\hline
\end{tabular}

İçe yönelim ve dışa yönelim sorunları ile demokratik tutum, ev kadınlığını reddetme ve evlilik çatışması alt boyutları arasındaki ilişkide aile işlevlerinin aracı rolünü ortaya konulmuştur. Dışa yönelim sorunları için, çocuk yetiştirme tutumunun alt boyutu olan artık boyut/disiplin, davranış

$\begin{array}{ll}\text { Makale } & \text { I. O. D. }(7-12)\end{array}$
kontrolünü etkilemekte; davranış kontrolü de dışa yönelim sorunları üzerinde etkili olmaktadır. Bunun yanı sıra, çocuk yetiştirme tutumunun demokratik tutum, ev kadınlığını reddetme ve evlilik çatışması alt boyutları, duygusal tepki vermeyi etkilemekte, duygusal tepki verme de dişa yönelim sorunları üzerinde etkili olmaktadır.

Enürezis problemi olan çocukların annelerinin olmayanlara göre çocuk yetiştirme tutumu alt boyunlarından karı-koca geçimsizliği puanı anlamlı de-

$\begin{array}{ll}\text { Makale } & \text { O. Ö. D. (0-6) }\end{array}$
recede yüksek bulunmuştur. Ayrıca anne-çocuk ilişkisinde sorun varlığının, anneden fiziksel şiddet görme, çocuğun aktivitelerinde kısıtlama, ebeveynlerinin çocukluğunda enürezis sorunu yaşaması değişkenleri enürezis ile ilişkili bulunmuştur.

$\begin{array}{ll}\text { Makale } & \text { E. D. (13-18) } \\ \text { \#27 } & \end{array}$

Ebeveynlerini otoriter olarak algılayan bireylerin, diğer bireylere göre daha fazla duygusal/eylemsel kaçma ve dıș yardım arama davranıșı gösterdikleri belirlenmiștir. Ayrıca, ebeveynleri otoriter tutum sergileyen bireylerin depresyon ortalamalarının daha yüksek olduğu görülmüştür.

$\begin{array}{ll}\text { Makale } & \text { E. D. (13-18) } \\ \text { \#28 } & \end{array}$

Ebeveyn tutumu ile öğrencilerin şiddet eğilimleri arasında istatistiksel olarak anlamlı bir fark bulunmamıştır. Otoriter tutuma sahip anne ya da babası olan öğrencilerin şiddet eğilim puanı, diğerlerine göre daha yüksek bulunmuştur ancak bu fark anlamlı değildir.

Anne baba tutumlarının madde kullanım bozukluğu olan ve olmayan grup arasında istatistiksel olarak anlamlı farklılık bulunmuştur. Madde kullanım

$\begin{array}{ll}\text { Makale } & \text { E. D. }(13-18) \\ \# 29 & \end{array}$
bozukluğu olan ergen grubunda "ihmalkar" anne baba tutumunun, kontrol grubunda ise demokratik anne baba tutumunun daha sık görüldügü belirlenmiştir.

Madde kullanım bozukluğu olan katılımcıların karşılaştırma grubuna göre,

$\begin{array}{ll}\text { Makale } & \text { E. D. }(13-18) \\ \# \mathbf{3 0} & \end{array}$
hem annelerinden hem de babalarından anlamlı olarak daha fazla ret, daha fazla kontrol; daha az kabul/ilgi ve daha fazla sıkı denetim/kontrol algıladıkları bulunmuştur. Çocuk yetiştirme stilleri açısından gruplar 


\begin{tabular}{|c|c|c|}
\hline & & $\begin{array}{l}\text { karşılaştırıldığında, madde kullanım bozukluğu olan genç yetişkinlerin ebev- } \\
\text { eynlerinin her ikisini de otoriter olarak algıladıkları görülmüştür. }\end{array}$ \\
\hline $\begin{array}{l}\text { Makale } \\
\# 31\end{array}$ & E. D. $(13-18)$ & $\begin{array}{l}\text { Madde kullanım bozukluğu olan ergenlerin ebeveynlerinin madde kullanım } \\
\text { bozukluğu olmayan ergenlerin ebeveynlerine göre; daha az otoriter ve dem- } \\
\text { okratik tutum gösterdikleri bulunmuştur. Ayrıca, madde kullanım bo- } \\
\text { zukluğu olan ergenlerin madde kullanım bozukluğu olmayan ergenlere göre, } \\
\text { ailelerinin daha az kabul-ilgi, kontrol-denetleme gösterdiği ve psikolojik } \\
\text { özerklik sağladığı belirlenmiştir. }\end{array}$ \\
\hline $\begin{array}{l}\text { Makale } \\
\# 32\end{array}$ & O. Ö. D. (0-6) & $\begin{array}{l}\text { Otoriter ebeveyn tutumu ile okul öncesi çocukluk döneminde ortaya çıkan } \\
\text { masturbasyon arasında doğrudan bir ilişki olduğu görülmüştür. Otoriter } \\
\text { ebeveyn tutumu çocukluk çağı masturbasyon bozukluğu olan çocuklarda } \\
\text { istatistiksel olarak yüksek bulunmuştur. }\end{array}$ \\
\hline $\begin{array}{l}\text { Makale } \\
\# 33\end{array}$ & O. Ö. D. (0-6) & $\begin{array}{l}\text { Anne ve babanın otoriter tutumu ile fiziksel ve ilişkisel saldırganlık arasında } \\
\text { pozitif yönde bir ilişki bulunurken, annenin izin verici tutumu ile fiziksel } \\
\text { saldırganlık arasında negatif yönde bir ilişki bulunmuştur. }\end{array}$ \\
\hline $\begin{array}{l}\text { Makale } \\
\# 34\end{array}$ & O. Ö. D. (0-6) & $\begin{array}{l}\text { Çalışmanın sonucunda çocukların davranış problemleri ile annelerin istismar } \\
\text { farkındalık düzeyleri ve izin verici tutuma sahip olmaları arasında pozitif } \\
\text { yönlü, annelerin demokratik tutuma sahip olmaları arasında ise negatif yönlü } \\
\text { bir ilişki bulunduğu saptanmıştır. İzin verici tutum gösteren ebeveynlerin, } \\
\text { çocuklarının davranış problemleri, kavgacı-saldırgan olmaları ve aşırı ha- } \\
\text { reketli ve dikkatsiz olmaları üzerinde etkisi bulunduğu belirlenmiştir. Ayrıca } \\
\text { demokratik tutumun çocukların kavgacı-saldırgan olmaları ile ters orantılı } \\
\text { etkiye sahip olduğu belirlenmiştir. }\end{array}$ \\
\hline $\begin{array}{l}\text { Makale } \\
\# 35\end{array}$ & O. Ö. D. (0-6) & $\begin{array}{l}\text { Anne babanın demokratik tutumu arttıkça çocuktaki saldırganlık yönelim- } \\
\text { inin azaldığı, anne babanın otoriter ve izin verici tutumu arttıkça çocuktaki } \\
\text { saldırganlık yöneliminin de artı̆̆ını görülmüştür. }\end{array}$ \\
\hline $\begin{array}{l}\text { Makale } \\
\# 36\end{array}$ & O. Ö. D. (0-6) & $\begin{array}{l}\text { Aşırı koruyucu anne baba tutum düzeyi arttıkça aşırı inatçılık davranışının } \\
\text { azaldığı, hayvan korkusunun ise arttığı; demokratik anne baba tutum düzeyi } \\
\text { arttıkça arttıkça içe kapanıklı, parmak emme ve fobilerin arttığı; ev } \\
\text { kadınlığını reddedici anne baba tutum düzeyi arttıkça arttıkça hayvan } \\
\text { korkusunun arttığı; sıkı disiplinli anne baba tutum düzeyi arttıkça hayvan } \\
\text { korkusu ve yalan söyleme davranışının arttığı belirlenmiştir. }\end{array}$ \\
\hline $\begin{array}{l}\text { Makale } \\
\# 37\end{array}$ & O. Ö. D. (0-6) & $\begin{array}{l}\text { Ebeveynlerine uygulanan eğitim programı anne baba tutumlarında, ebev- } \\
\text { eynlerin ruh sağlığı düzeylerinde, çocukların problemli davranışlarını azalt- } \\
\text { mada anlamlı düzelme sağlamıştır. }\end{array}$ \\
\hline $\begin{array}{l}\text { Makale } \\
\# 38\end{array}$ & E. D. (13-18) & $\begin{array}{l}\text { Öğrencilerin zorba kişilik düzeylerinin en önemli açıklayıcılarından biri anne } \\
\text { tutumu olarak belirlenmiştir. Ancak baba tutumu, öğrencilerin zorba kişilik } \\
\text { puanlarının önemli bir açıklayıcısı olmadığı görülmüştür. }\end{array}$ \\
\hline $\begin{array}{l}\text { Makale } \\
\# 39\end{array}$ & O. Ö. D. (0-6) & $\begin{array}{l}\text { Ebeveynlerin demokratik ve otoriter tutumlarının çocukların sosyal yetkinlik } \\
\text { ve içe dönüklük davranışlarını anlamlı düzeyde yordadığı görülmüştür. }\end{array}$ \\
\hline $\begin{array}{l}\text { Makale } \\
\# 40\end{array}$ & E. D. $(13-18)$ & $\begin{array}{l}\text { Aile ortamında baskıcı, aşırı disiplinli, ilgisiz ve tutarsız ebeveyn tutumuna } \\
\text { maruz kalan suça sürüklenen çocukların çocukluk çağı ruhsal travmalarını } \\
\text { daha fazla yaşadıkları saptanmıştır. }\end{array}$ \\
\hline $\begin{array}{l}\text { Makale } \\
\# 41\end{array}$ & E. D. (13-18) & $\begin{array}{l}\text { Suça sürüklenen çocuklar ve suça sürüklenmeyen çocukların algıladıkları } \\
\text { hem anne hem de baba tutumları arasında istatistiksel olarak anlamlı ilişki } \\
\text { bulunmuştur. Anne tutumu demokratik ve hoşgörülü olan çocuklarda suça } \\
\text { sürüklenenlerin oranı anne tutumu ihmalkâr olanlardan anlamlı düzeyde } \\
\text { yüksektir. Baba tutumu demokratik olan çocuklarda suça sürüklenenlerin } \\
\text { oranı baba tutumu ihmalkâr olanlara göre anlamlı düzeyde yüksek bulun- } \\
\text { muştur. }\end{array}$ \\
\hline
\end{tabular}


Tablo 11. incelendiğinde genel olarak izin verici, otoriter, demokratik ve aşırı koruyucu olarak sıralanan ebeveyn tutumlarının tamamının farklı yaş düzeylerinde farklı şekillerde duygusal ve davranışsal problemleri etkilediği görülmektedir. İncelenen çalışmaların sonuçlarına bakıldığında, izin verici tutum sergileyen ebeveynlerin ergenlik dönemindeki çocuklarında arkadaşlarına bağllık ve internet bağımlılığının diğer tutuma sahip ebeveynlerin çocuklarına göre daha fazla olduğu görülmüştür. Ayrıca yine bu tutuma sahip ailelerde yetişen ergenlerde madde kullanım bozukluğunun yüksek olduğu bulunmuştur. İzin verici tutuma sahip ailelerde yetişen okul öncesi dönem çocuklarında saldırganlık yöneliminin ve ayrılık kaygısının arttı̆̆ı, sosyal uyumun ise düşük olduğu tespit edilmiştir. Ek olarak okul öncesi dönem çocuğu olan annelerin izin verici tutuma sahip olmasının fiziksel saldırganlığı azalttığı görülmüştür. Demokratik tutuma sahip ebeveynlerin yetiştirdiği ergenlik dönemindeki çocuklarda saldırganlığın ve kaygının azaldığı, problem çözme becerilerinin arttığı, diğer tutumlara sahip ailelerin çocuklarına göre daha az problem davranışla karşılaşıldığı tespit edilmiştir. Ayrıca anne ve babaların demokratik tutuma sahip olmasının ergenlik dönemindeki çocuklarda suça sürüklenmeyi arttırdığı görülmüştür. Okul öncesi dönem çocuklarında demokratik tutuma sahip ebeveynlerin etkisi, yetişkin ayrılık kaygısını negatif yönde etkileme, sosyal uyumu arttırma, kavgacı olma ve saldırganlık yönelimini azaltma, içe kapanıklık, parmak emme ve fobileri arttırma şeklinde ortaya çıkmaktadır.

Aşırı koruyucu tutuma sahip ebeveynlerin yetiştirdiği çocuklarda ergenlik döneminde saldırganlık ve dışa atım bozuklukları oluştuğu görülmüştür. Okul öncesi dönem çocuklarını ise hayvan korkusunu ve ayrılık kaygısını arttırma, aşırı inatçlığı ve sosyal uyumu azaltma şeklinde etkilediği ortaya konulmuştur. Ayrıca, ebeveynlerin aşırı koruyucu tutumda olmasının okul öncesi çocukların içe yönelim davranışları ile ilişkili olduğu bulunmuştur.

Otoriter tutuma sahip ebeveynlerin ergenlik dönemindeki çocuklarının saldırgan davranışlar gösterdiği, problem çözme becerilerinin olumsuz etkilendiği, duygusal-eylemsel kaçınma yaşadıkları, depresyona eğilimli oldukları, madde kullanım bozukluğuna sahip olabilecekleri görülmüştür. Okul öncesi dönemdeki çocuklarda ise akran şiddetine maruz kalma çocukluk çağı mastürbasyonunu tetiklediği, 
fiziksel ve ilişkisel saldırganlığı, hayvan korkusunu, yalan söylemeyi, ayrılık kaygısını arttırdığı ve sosyal uyumu azalttığı ortaya konulmuştur. Otoriter tutumla yetişen ilkokul çağındaki çocukların da saldırganlıklarının yüksek olduğu tespit edilmiştir.

Tablo 11'de görülen araştırma sonuçlarına bakıldığında, anne baba tutumlarının çocukların duygusal ve davranışsal problemlerini etkilemesinin yanında, çocukların bu problemlerinin anne baba tutumlarını etkileyebildiği görülmektedir. Örneğin OSB tanılı çocuğa sahip ebeveynlerin, diğer ebeveynlere göre daha başarı odaklı ve yönlendirici olduğu, çocukları tarafından yeterince duyarlı ve yanıtlayıcı olarak tanımlanmadığı görülmüsstür. Diğer taraftan DEHB tanılı çocuklar ebeveynlerini daha reddedici ve denetlemesi az olarak tanımlarken, bu çocukların annelerinin daha sıkı disiplin uyguladıkları ve daha az demokratik oldukları bulunmuştur. Ayrıca yine DEHB tanılı çocuğa sahip ebeveynler arasından kadınların ev içi sorumluluklarını daha çok reddettiği ve aile içerisinde eşler arası geçimsizliğin daha sıklıkla yaşandığına ilişkin sonuçlar elde edilmiştir.

\section{Tartışma ve Sonuç}

2005-2020 yılları arasında ulusal veri tabanlarında (Dergipark, Ulakbim ve Acarindex) yayınlanmış olan 0-18 yaş aralığında duygusal ve davranışsal problemler ile ebeveyn tutumlarını konu edinen makalelerin incelendiği bu araştırmanın sonucunda, toplamda 41 makale incelenmiş olup bu makalelerden 20 tanesinin Dergipark veri tabanında, 20 tanesinin Ulakbim veri tabanında ve bir tanesinin ise Acarindex veri tabanında yayınlandığ1 görülmektedir. Bu durumda ulusal veritabanlarında duygusal ve davranışsal problemlerin ebeveyn tutumları ile birlikte ele alındığı makalelerin çoğunluğunun Ulakbim ve Dergipark veri tabanlarında yer aldığı sonucuna ulaşılmıştır.

Araştırmada incelenen makalelerin yıllara göre dağılımlarına bakıldığında ise, 2018 ve 2019 yıllarında araştırmaya dahil edilen makalelerin diğer yıllara göre daha fazla yoğunlaştığı görülmektedir. 2007, 2008, 2009 ve 2011 yıllarında ise konu ile ilgili makalelere rastlanmamıştır. 2020 yılı içerisinde yayınlanan makalelerin diğer yıllara göre sayıca az olması Covid19 sürecinin olumsuz etkileri ile açılanabilir. 
Araştırma kapsamında incelenen makalelerde yer verilen duygusal ve davranışsal bozuklukların dağılımı incelendiğinde en fazla çalışılan problemin davranım bozukluğu, en az çalışılan problemlerin ise otizm spektrum bozukluğu, iletişim bozukluğu, antisosyal kişilik bozukluğu, internet bağımlılığı ve çocukluk çağı mastürbasyon bozukluğu olduğu görülmüştür. En fazla çalışılan duygusal ve davranışsal problem olan davranım bozukluğunu ise dikkat eksikliği ve hiperaktivite bozukluğu takip etmektedir. Çalışma bulguları ile uyumlu bir şekilde Ayanoğlu ve diğerleri (2019) lisansüstü tezleri inceledikleri çalışmada en fazla konu edinilen problemin dikkat eksikliği ve hiperaktivite bozukluğu olduğunu ortaya koymuştur.

Yayınlanan makaleler disiplin alanlarına göre incelendiğinde, konunun en fazla "eğitim bilimleri", en az ise "sağlık bilimleri" alanlarında çalışıldığı görülmüştür. Eğitim bilimleri alanı içerisinde ise en fazla okul öncesi eğitim bilim dalında çalışılırken, en az özel eğitim bilim dalında çalışıldığı tespit edilmiştir. Bununla birlikte, lisansüstü tezlerin incelendiği çalışmada ise dahil edilen örneklem grupları arasında en fazla çalışılan gruplardan birinin okul öncesi dönem çocukları olduğu ortaya konmuştur (Ayanoğlu ve diğerleri, 2019). Ek olarak makalelerin örneklem grubu incelendiğinde çalışmalara en fazla ergenlik ve okul öncesi dönemin dahil edildiği görülmüştür.

Ulusal veri tabanlarında taranan makalelerde kullanılan araştırma yöntemlerinin dağılımına bakıldığında ise hem duygusal ve davranışsal problemlerin tespiti hem de ebeveyn tutumunu belirlemek amaciyla büyük çoğunlukla nicel yöntemin kullanıldığı görülmüştür. Ebeveyn tutumlarının çocuğun psikolojisi üzerindeki etkilerini ortaya koymak amacıyla yapılan derleme çalışmasının ve konu ile ilgili lisansüstü tezlerin incelendiği makalenin sonuçları da benzer şekilde nicel yöntemin daha fazla kullanıldığını ortaya koymuştur (Ayanoğlu ve diğerleri, 2019; Sümer, Gündoğdu-Aktürk ve Helvacı, 2010).

Çalışma sürecinde incelenen makalelerin sonuçları incelendiğinde anne babaların sergilediği ebeveynlik tutumlarının çocuğun duygusal ve davranışsal problemleri üzerinde etkisi olduğu ve buna ek olarak çocukların halihazırda yaşamakta olduğu duygusal ve davranışsal problemlerin de ebeveynlik tutumları üzerinde etkili olabildiği görülmüştür. Ulusal ya da uluslararası alan yazında konuya yönelik yapılmış çalışmaların so- 
nuçlarına bakıldığında da mevcut araştırmada elde edilen sonuç ile paralel olarak ebeveyn tutumlarının çocuklardaki duygusal ve davranışsal problemler üzerinde etki sahibi olduğu ortaya konulmuştur. Demokratik tutuma sahip ebeveynlerin çocuklarının daha az sıklıkla davranışsal problemler yaşadıkları ve daha yüksek akademik başarıya sahip oldukları tespit edilmiştir (Alizadeh, Talib, Abdullah ve Mansor, 2011). Yine mevcut çalışmanın sonuçları ile uyumlu olarak, okul öncesi dönemde rastlanan içselleştirici ve dışsallaştırıcı davranışsal problemler ile ilgili yapılan bir araştırmada izin verici tutum sergileyen ebeveynlerinin çocuklarının okul öncesi dönemde daha fazla içselleştirici davranış problemleri yaşadıkları belirtilmiştir (Williams ve diğerleri, 2009). Tüm bulgulardan farklı olarak, anne ve babaların demokratik tutuma sahip olmasının ergenlik dönemindeki çocuklarda suça sürüklenmeyi arttırdığı bulgusuna rastlanmıştır. Demokratik tutumun olumlu davranış geliştirme de, duygusal ve davranışsal problemlerin azalmasında etkili olduğu ve çoğu çalışmada ebeveynlerin demokratik tutuma sahip olması vurgulanmaktadır. Ancak, bu bulgu her gelişim döneminin özelliğine göre ebeveynlerin farklı tutumları duruma göre kullanarak çocuklarını kötü alışkanlıklardan, suça sürüklenmekten ya da problemlerden koruyabileceği gerçeğini düşünmemizi sağlamıştır. Farklı ebeveyn tutumlarını doğru ve akılcı kullanabilmenin bilinçli anne baba olmayı, çocuk ve ergen gelişimi ve psikolojisini bilmeyi gerektirdiğini de unutmamak gerekir. Çalışmanın bulguları ışığında duygusal ve davranışsal problemlere yönelik müdahale programlarının hazırlanması, nicel yöntemlerin yanında nitel ve karma yöntemlerinde kullanılması ve ayrıca meta analiz, içerik analizi gibi çalışmalara daha fazla ağırlık verilmesi önerilmektedir. 


\section{EXTENDED ABSTRACT}

\section{Examining the Relationship between Emotional and Behavioral Problems and Parental Attitude: Content Analysis \\ *}

Aysel Çoban- Zehra Bilgen- Özge İdrisoğlu- İlyas Sönmez- Hatice Berna Türe Köse - Hatice Ünlü Bozkurt

Hacettepe University-Onsekiz Mart University-F. Sultan Mehmet University-Hacettepe University-Dumlupinar University-Gelişim University

When children and adolescents show negative emotional and behavioral reactions even though they know that these behaviors are not suitable for their age, social and cultural structure of the society and they are capable of showing positive reactions, it is considered as problem behavior (Özel Eğitim Hizmetleri Yönetmeliği, 2006; Birkan, 2002). A problem behavior must be continuous, affect the child's life negatively, be in a situation that requires intervention, and have other maladaptive behaviors (Campbell, 1995). Emotional and behavioral problems are clasified into internalizing and externalizing. While it is difficult to observe internalizing behaviors, externalizing problems can be observed in behavior (Austin and Sciarra, 2019).

The emergence of emotional and behavioral problems in children and adolescents can be caused by various situations such as parental attitudes, poverty in the family, violence, communication problems, genetic factors, negative parental behaviors, traumas (Ar1, 2005; Arkan and Üstün, 2009; Conroy and Brown, 2004). Therefore, the parental attitude is an important factor in behavioral problems of children and adolescents. By revealing the relationship between emotional and behavioral problems and parental attitudes, an overview will be provided a view to practitioners and parents in the field, in addition to professionals and researchers working on this subject.

For this purpose, it was aimed to examine the several articles related with the parental attitudes and emotional and behavioral problems. In 
other words published articles with thematic content analysis were examined in different subject areas such as problem areas, age, discipline areas, scales.

In this research, the thematic content analysis (meta-synthesis) method was used to analyze the studies on emotional and behavioral problems and parental attitudes. Meta-synthesis (thematic content analysis), one of the content analyses, synthesizes and interprets the researches on the same subject by creating themes (Çalık and Sözbilir, 2014).

The articles published between 2005 and 2020 on emotional and behavioral problems and parental attitudes in national databases were analyzed in terms of various variables. The articles for the thematic content analysis were scanned and selected according to the criteria determined by the researchers. While selecting the articles based on the criteria, it was considered that they were made in Turkey, published between 2005-2020, and studied with the 0-18 age group. Articles that were studied for the adult age group, articles that did not study parental attitudes, and review articles were excluded from the study.

For this research, 3 national databases which provide credible data and access to a large number of academic journals were selected and searched. Also, these databases were analyzed based on certain keywords. To examine emotional and behavioral problems in a comprehensive way, each problem type has been searched as a keyword.

As a result of the searching, 41 articles that met the criteria were examined based on the categories of "database, year, problem type, method, discipline area, study area, research method, age group, data collection tool and the relationship between problems and parental attitude". The results were presented with graphs and frequency tables.

To ensure reliability, the articles were analyzed and re-evaluated by all researchers. Miles and Huberman (1994) suggested the formula for intercoder reliability which is "Reliability $=$ Number of Agreements / (Number of Agreements + Disagreement) ${ }^{*} 100$ ". In this study, the calculations were made according to the formula and the inter-coder reliability was found $\% 88$.

The findings shows that 41 articles were published in three different databases. When it was looked at the distribution of the articles according to the database, it was found that the most articles were published in the 
"Dergipark" and "Ulakbim" databases. According to the distribution of the articles by years, it is concluded that the most articles were published in 2018 and 2019. When the types of emotional and behavioral problems in the articles were analyzed, it was determined that the most emotional and behavioral problems were in the type of conduct disorder.

Based on the findings of the disciplines of the articles, it is seen that the field of "Educational Sciences" is the most articles are published. Also, it was found that "Pre-School Education" constituted the study area in which the most articles were published. When the distribution of the articles by age groups was examined, it was seen that the most examined age group was adolescence. It was determined that the most quantitative research method was used in terms of research method in articles about parental attitudes and emotional and behavioral problems. In the articles, 7 measurement tools were used to measure parental attitude. It was determined that total of 36 different measurement tools were used to measure the types of emotional and behavioral problems. Finally, it was concluded that parental attitudes affect emotional and behavioral problems and also the problems of children can affect parental attitudes. The reciprocal relations were found out results of the articles.

As a result of this research, a total of 41 articles published in national databases were examined. It is seen that 20 of the articles were published in Dergipark, 20 in Ulakbim and 1 in Acerindex database. Considering the years in which the studies were published, there were no articles on the subject in 2007, 2008, 2009 and 2011. It is seen that the most studies were done in 2018 and 2019.

Considering the emotional and behavioral problems in the articles, it was seen that the most studied problem was conduct disorder, the least studied problems were autism spectrum disorder, communication disorder, antisocial personality disorder, internet addiction and childhood masturbation disorder. Consistent with the findings of the study, Ayanoğlu et al. (2019) revealed that the most common problem in their study, in which they examined postgraduate theses, is attention deficit and hyperactivity disorder.

When the published articles are examined according to the discipline areas, it is seen that the subject is mostly studied in educational sciences, and it is mostly studied in the field of preschool education. 
Considering the research methods used in the articles examined, it was seen that the quantitative method was generally used to determine both emotional behavioral disorders and parental attitudes. Studies have shown that the quantitative method is used on similar subjects (Ayanoğlu et al., 2019; Sümer, Gündoğdu-Aktürk and Helvac1, 2010).

As a result it has been found that parental attitudes are effective in the development of emotional and behavioral problems in children. It has been revealed that while children growing up in families with a democratic attitude have fewer behavioral problems (Alizadeh, Talib, Abdullah and Mansor, 2011), children from families with permissive parenting styles have more internalizing behavior problems (Williams et al., 2009). In the light of the findings of the studies, it is recommended to prepare intervention programs for emotional and behavioral problems, to use qualitative and mixed methods besides quantitative methods, and to concentrate on studies such as meta-analysis and content analysis.

\section{Kaynakça/References}

Alizadeh, S., Talib, M. B. A., Abdullah, R. and Mansor, M. (2011). Relationship between parenting style and children's behavior problems. Asian Social Science, 7(12), 195-200.

Arı, R. (2005). Gelişim ve öğrenme (2. Baskı). Ankara: Nobel Yayın Dağıım.

Austin, V. L. and Sciarra, D. T. (2019). Çocuk ve ergenlerde duygusal ve davranışsal bozukluklar. (Çev. Ed. Özekes, M.). Ankara: Nobel Akademik Yayıncllı. (Orijinal eserin basım tarihi 2010).

Arkan, B. ve Üstün, B. (2009). Davranım bozukluğu olan çocuklara psikiyatrik yaklaşımda anne-baba eğitim programları: İki örnek bağlamında bir değerlendirme. Psikiyatride Güncel Yaklaşımlar, 1, 155-174.

Ayanoğlu, M., Boğa, E., Kay, M., İnci, R., Tarkoçinn, S., Kaçmaz, C., Temiz, A. ve Göğebakan, Ş. (2019). Çocukluk döneminde görülen duygusal ve davranışsal sorunlarla ilgilï Türkiye'de yapılan lisansüstü tezlerin incelenmesi. İnönü Üniversitesi Sağlık Hizmetleri Meslek Yüksek Okulu Dergisi, 7(2), 196-210. DOI: 10.33715/inonusaglik.654600.

Baumrind, D. (1966). Effects of authoritative parental control on child behavior. Child Development, 37(4), 887-907.

Baumrind, D. (1971). Current patterns of parental authority. Developmental Psychology, 4(1), 1-103. 
Beard, K. Y. and Sugai, G. (2004). First step to success: An early intervention for elementary children at risk for antisocial behavior. Behavioral Disorders, 29(4), 396-409.

Birkan, B. (2002). Çocuklarda davranış sorunları ve başa çıkma yolları. Çoluk Çocuk Aylı Anne Baba Ĕ̆itimci Dergisi, 17, 18-20.

Büyüköztürk, Ş., Kılıç-Çakmak, E., Akgün, Ö. E., Karadeniz, Ş. ve Demirel, F. (2012). Bilimsel araştırma yöntemleri (12. baskı). Ankara: Pegem Akademi Yayıncilik.

Campbell, S. B. (1995). Behavior problems in preschool children: A review of recent research. Journal of Child Psychology \& Psychiatry, 36(1), 113-149.

Cancio, E. J. and Johnson, J.W. (2013). Designing effective class wide motivation systems for students with emotional and behavioral disorders. Preventing School Failure: Alternative Education for Children and Youth, 57(1), 49-57.

Conroy, M. A. and Brown, W. H. (2004). Early identification, prevention, and early intervention with young children at-risk for emotional/behavioral disorders: Issues, trends, and a call for action. Behavioral Disorders, 29(3), 224-236.

Creswell, J. W. (2017). Araştırma deseni: Nitel, nicel ve karma yöntem yaklaşımları. (Çev. Demir, S. B.). Ankara: Eğiten Kitap. (Orijinal eserin basım tarihi 2014, 4. Bask1).

Çalık, M. ve Sözbilir, M. (2014). İçerik analizinin parametreleri. Eğitim ve Bilim Dergisi, 39(174), 33-38.

Golly, A., Sprague, J., Walker, H. M., Beard, K. and Gorham. G. (2000). The first step to success program: An snalysis of outcomes with identical twins across multiple baselines. Behavioral Disorders, 25(3), 170-182.

Hale, R. (2008). Baumrind parenting styles and their relationship to the parent developmental theory. (Yayımlanmamış doktora tezi). Pace University, New York City, United States of America.

Karabulut-Demir, E. (2007). Ebeveyn tutum ölçĕği (ETÖ). (Yayımlanmamış yüksek lisans tezi). İstanbul Üniversitesi, Sosyal Bilimler Enstitüsü, İstanbul.

Kızıltepe, Z. (2021). İçerik analizi. F. N. Seggie ve Y. Bayyurt (Ed.). Nitel araştırma: Yöntem, teknik, analiz ve yaklaşımları içinde (s.260-273), (3. Baskı). Ankara: Anı Yayıncilik.

Miles, M. B. and Huberman, A. M. (1994). Qualitative data analysis: An expanded sourcebook. (2nd ed.). California, USA: SAGE Publications. 
Özel Eğitim Hizmetleri Yönetmeliği (2006). Erişim Adresi: https://www.resmigazete.gov.tr/eskiler/2006/05/20060531-2.htm. Erişim tarihi: 20 Şubat 2021

Senemoğlu, N. (2009). Gelişim öğrenme ve öğretim, kuramdan uygulamaya. Ankara: Pegem Akademi.

Suri, H. and Clarke, D. (2009). Advancements in research systhesis methods: From a methodologically inclusive perspective. Review of Educational Research, 79(1), 395-430.

Sümer, N., Gündoğdu-Aktürk, E. ve Helvacı, E. (2010). Anne-baba tutum ve davranışlarının psikolojik etkileri: Türkiye'de yapılan çalışmalara toplu bakış. Türk Psikoloji Yazıları, 13(25), 42-59.

Trawick-Smith, J. (2017). Erken çocukluk döneminde gelişim: Çok kültürlü bir bakış açısı. (Çev. Ed. Akman, B.). Ankara: Nobel Akademik Yayıncılık. (Orijinal eserin basım tarihi 2010, 5. Baskı).

Williams, L. R., Degnan, K. A., Perez-Edgar, K. E., Henderson, H. A., Rubin, K. H., Pine, D. S. and Fox, N. A. (2009). Impact of behavioral inhibition and parenting style on internalizing and externalizing problems from early childhood through adolescence. Journal of Abnormal Child Psychology, 37(8), 1063-1075.

Yavuzer, H. (2008). Çocuk psikolojisi. İstanbul: Remzi Kitabevi

\section{Kaynakça Bilgisi / Citation Information}

Çoban, A., Bilgen, Z., İdrisoğlu, Ö., Sönmez, İ., Türe Köse H. B. ve Bozkurt Ünlü H. (2021). Karşılaşılan duygusal ve davranışsal problemlerin ebeveyn tutumu ile ilişkisinin incelenmesi: İçerik analizi. OPUSUluslararası Toplum Araştırmaları Dergisi, 18(Eğitim Bilimleri Özel Sayıs1), 4302-4335. DOI: 10.26466/opus.907851. 